\title{
Chapter 7 \\ Modelling Future Growth of Mountain Forests Under Changing Environments
}

\author{
Michal Bosela, Katarína Merganičová, Chiara Torresan, Paolo Cherubini, \\ Marek Fabrika, Berthold Heinze, Maria Höhn, Milica Kašanin-Grubin, \\ Matija Klopčič, Ilona Mészáros, Maciej Pach, Katarina Střelcová, \\ Christian Temperli, Giustino Tonon, Hans Pretzsch, and Roberto Tognetti
}

\begin{abstract}
Models to predict the effects of different silvicultural treatments on future forest development are the best available tools to demonstrate and test possible climate-smart pathways of mountain forestry. This chapter reviews the state of the art in modelling approaches to predict the future growth of European mountain forests under changing environmental and management conditions. Growth models, both mechanistic and empirical, which are currently available to predict forest
\end{abstract}

The author Giustino Tonon died prior to the publication of this chapter.

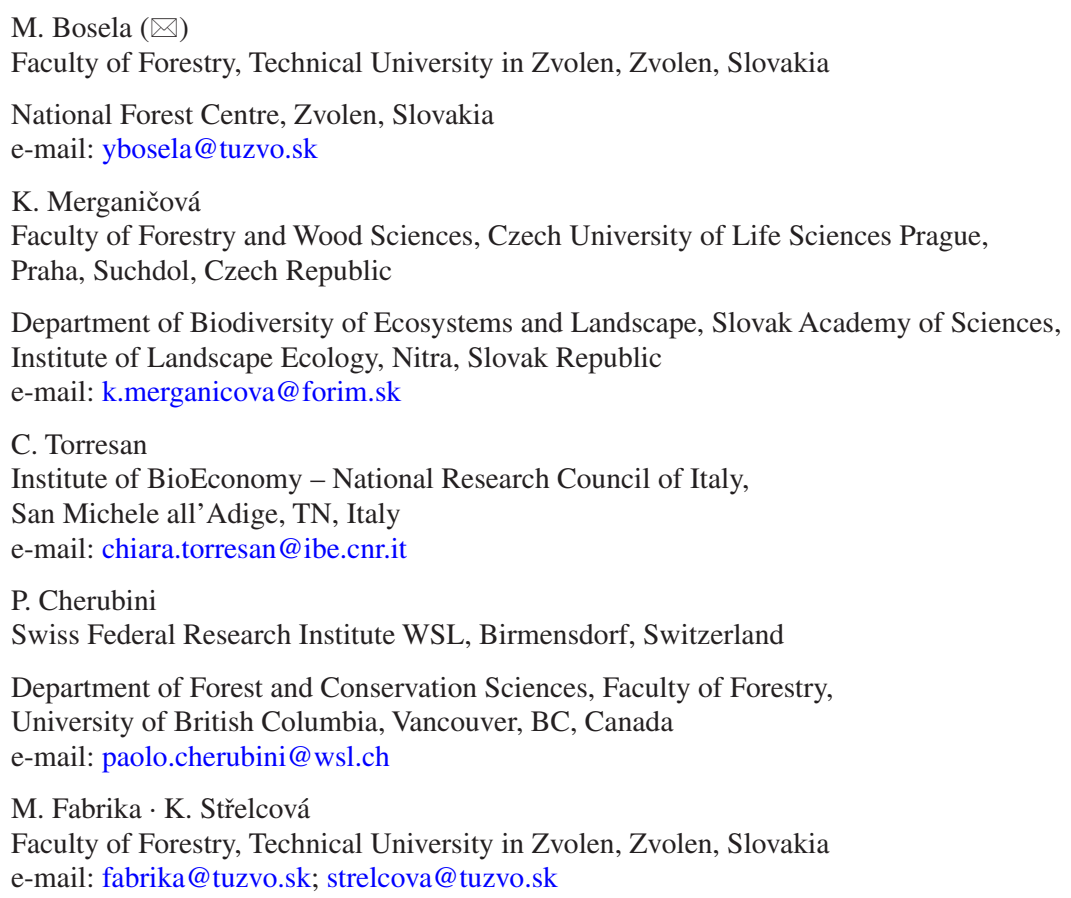


growth are reviewed. The chapter also discusses the potential of integrating the effects of genetic origin, species mixture and new silvicultural prescriptions on biomass production into the growth models. The potential of growth simulations to quantify indicators of climate-smart forestry (CSF) is evaluated as well. We conclude that available forest growth models largely differ from each other in many ways, and so they provide a large range of future growth estimates. However, the fast development of computing capacity allows and will allow a wide range of growth simulations and multi-model averaging to produce robust estimates. Still, great attention is required to evaluate the performance of the models. Remote sensing measurements will allow the use of growth models across ecological gradients.

\section{B. Heinze}

Department of Forest Genetics, BFW Austrian Federal Research Centre for Forests, Vienna, Austria

e-mail: berthold.heinze@bfw.gv.at

M. Höhn

Department of Botany, Budai Campus, Hungarian University of Agriculture and Life

Sciences, Budapest, Hungary

e-mail: hohn.maria@uni-mate.hu

M. Kašanin-Grubin

University of Belgrade, Institute for Chemistry, Technology and Metallurgy, Beograd, Serbia e-mail: mkasaningrubin@chem.bg.ac.rs

\section{Klopčič}

Biotechnical Faculty, Department of Forestry and Renewable Forest Resources, University of Ljubljana, Ljubljana, Slovenia

e-mail: matija.klopcic@bf.uni-lj.si

\section{Mészáros}

Faculty of Science and Technology, Department of Botany, University of Debrecen, Debrecen, Hungary

e-mail: immeszaros@unideb.hu

\section{Pach}

Department of Ecology and Silviculture, Faculty of Forestry, University of Agriculture in Krakow, Krakow, Poland

e-mail: rlpach@cyf-kr.edu.pl

C. Temperli

Swiss Federal Institute for Forest, Snow and Landscape Research WSL,

Birmensdorf, Switzerland

e-mail: christian.temperli@wsl.ch

G. Tonon (deceased)

\section{H. Pretzsch}

Chair for Forest Growth and Yield Science, TUM School of Life Sciences in Freising

Weihenstephan, Technical University of Munich, Freising, Germany

e-mail: Hans.Pretzsch@tum.de

\section{R. Tognetti}

Dipartimento Agricoltura, Ambiente e Alimenti, Università degli Studi del Molise,

Campobasso, Italy

Centro di Ricerca per le Aree Interne e gli Appennini (ArIA), Università degli Studi del

Molise, Campobasso, Italy

e-mail: tognetti@posta.unimol.it 


\section{Acronyms}

$\begin{array}{ll}\text { CSF } & \text { Climate-smart forestry } \\ \text { C } & \text { Carbon } \\ \text { CO}_{2} & \text { Carbon dioxide } \\ \text { GHG } & \text { Greenhouse gas } \\ \text { GCM } & \text { Global climate model } \\ \text { RCM } & \text { Regional climate models } \\ \text { IPCC } & \text { Intergovernmental Panel on Climate Change } \\ \text { SRES } & \text { Special Report on Emissions Scenarios } \\ \text { RCP } & \text { Representative Concentration Pathway } \\ \text { AR5 } & \text { Fifth Assessment Report } \\ \text { YM } & \text { Yield model } \\ \text { EM } & \text { Empirical model } \\ \text { PM } & \text { Mechanistic models } \\ \text { ES } & \text { Growth simulator } \\ \text { SES } & \text { Hybrid (semi-empirical) model } \\ \text { SFM } & \text { Sustainable forest management } \\ \text { TRW } & \text { Tree-ring width } \\ \text { VS } & \text { Vaganov-Shashkin } \\ \text { LDM } & \text { Landscape dynamics or forest landscape model } \\ \text { NFI } & \text { National forest inventory } \\ \text { EFDM } & \text { European Forest Dynamics Model } \\ \text { EFISCEN } & \text { European Forest Information Scenario model } \\ \text { ICP Forests } & \text { International Co-operative Programme on Assessment and Monitoring } \\ & \text { of Air Pollution Effects on Forests } \\ \text { EC } & \text { Eddy covariance } \\ \text { NEP } & \text { Net ecosystem productivity } \\ \text { MODIS } & \text { Moderate Resolution Imaging Spectroradiometer } \\ \text { GPP } & \text { Gross primary productivity } \\ \text { NPP } & \text { Net primary productivity } \\ \text { LUE } & \text { Light-use efficiency } \\ \text { APAR } & \text { Absorbed photosynthetically active radiation } \\ \text { NDVI } & \text { Normalised difference vegetation index } \\ \text { PAR } & \text { Photosynthetically active radiation } \\ \text { ER } & \text { Ecosystem respiration } \\ \text { LiDAR } & \text { Light detection and ranging } \\ \text { SAR } & \text { Synthetic aperture radar } \\ \text { EVI } & \text { Enhanced vegetation index } \\ \text { NDWI } & \text { Normalized difference water index } \\ \text { WDRVI } & \text { Wide dynamic range vegetation index } \\ \text { PI } & \text { Phenology index } \\ \text { LAI } & \text { Leaf area index } \\ \text { DA } & \text { Data assimilation } \\ & \end{array}$




$\begin{array}{ll}\text { ALS } & \text { Airborne laser scanning } \\ \text { TRW } & \text { Tree ring width } \\ \text { ITRDB } & \text { International Tree-Ring Data Bank } \\ \text { NCEI } & \text { National Centers for Environmental Information }\end{array}$

\subsection{Introduction}

Globally, the forest sector plays a crucial role in climate change mitigation because forests store a significant amount of carbon (C) and absorb around 30\% of the annual anthropogenic global carbon dioxide $\left(\mathrm{CO}_{2}\right)$ emission. For example, Pan et al. (2011) estimated a total forest sink of $2.4 \pm 0.4$ petagrams of $\mathrm{C}$ per year $(\mathrm{Pg} \mathrm{C}$ year $^{-1}$ ) globally from 1990 until 2007. However, in the same study, the authors estimated a $\mathrm{C}$ source of $1.3 \pm 0.7 \mathrm{Pg} \mathrm{C}$ year $^{-1}$ due to land-use change in the tropical forests.

Climate change imposes direct effects on forest ecosystems through increasing the concentration of atmospheric $\mathrm{CO}_{2}$ or change in temperature and precipitation (Keenan et al. 2013). Individual organisms living in forest ecosystems respond to climate change in different ways. If their adaptation to new environmental conditions is successful, forest ecosystems continue to provide ecosystem services specific to the type of forest ecosystem, and, by storing $\mathrm{C}$, they can significantly aid in mitigating the impacts of climate change too (Fig. 7.1). However, signs of C saturation in European (Nabuurs et al. 2013) and tropical (Hubau et al. 2020) forests indicate that forests cannot infinitely absorb $\mathrm{CO}_{2}$. Moreover, trees can adapt to new conditions by reducing their biomass production, which may, in turn, lessen the mitigation effect (Sperry et al. 2019).

Forestry actions that lead to a reduction in greenhouse gas (GHG) emissions and maximise carbon sequestration are considered climate-smart (Nabuurs et al. 2018; Yousefpour et al. 2018). The recently developed comprehensive definition of climate-smart forestry suggests that it should enable forest practitioners to

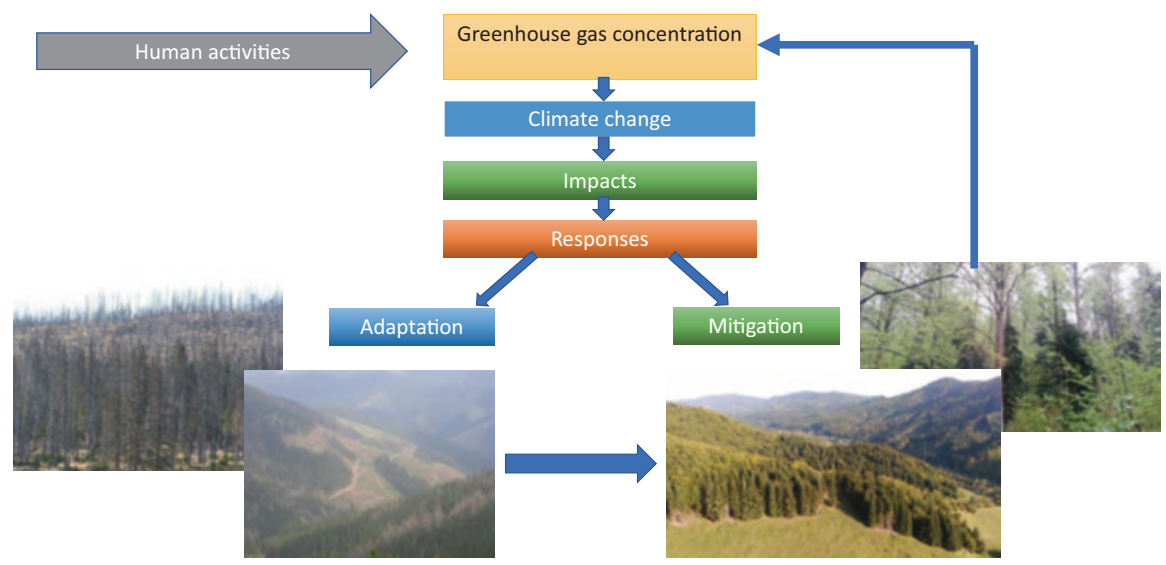

Fig. 7.1 Scheme describing the links between climate change and forests and the role of forests in mitigation of climate change impacts 
transform management targets, allowing forests to adapt to and mitigate climateinduced changes while delivering other services to the society (Bowditch et al. 2020).

Mountain forests (for a definition see, e.g., Kapos et al. 2000), are particularly affected by environmental changes, because they are energy and temperature limited, and potentially exposed to warming-induced drought stress (Albrich et al. 2020). In addition, mountain forests are further exposed to and affected by largescale wind disturbances, frequently followed by outbreaks of pests and fungal diseases (Seidl et al. 2014). Therefore, forest policy decision-makers and forest managers need to be advised by science about the potential and vulnerability of different tree species under predicted climate change.

Predictions by growth models are the best available source of information to optimise forest management and to assess the potential adaptation of the forests to climate change and the mitigation of climate change by the forests. Forest growth models have the potential to test many different variants of forest management, including various species compositions and silvicultural systems, from stand to regional or landscape levels (Fontes et al. 2010; Kramer et al. 2010; Merganič et al. 2020). Example applications of growth models include prediction of future yields, exploration of silvicultural options, preparing resource forecasts, providing insights into stand dynamics, etc. Growth models are generally classified into (i) empirical and (ii) process-based (also known as mechanistic) models. Empirical models are based on empirical equations (regression functions) describing particular relationships without knowing the causal mechanism of the complex system (Fontes et al. 2010; Mäkelä et al. 2012). In contrast, process-based models are based on a theoretical understanding of relevant ecological processes.

Currently, not all available models can test different management variants relevant for ecosystem management and ecopolitical decisions. In the following sections, we review the potential of various models to test the effects of climate change on the growth (the difference in standing volume between the beginning and end of a specified period of time) and productivity (the potential amount of wood produced by the forest within a specified time period, usually rotation period) of mountain forests and their potential to continue to be or become climate-smart.

\subsection{Prediction of Future Climate Conditions}

To obtain consistent predictions of future tree and forest growth, reliable past climate data as well as predictions of future climate in specific spatial and temporal resolutions must be provided as input into growth models and simulators. To obtain past climate data, spatially interpolated databases at varying spatial and temporal resolutions have been developed (Harris et al. 2014; Moreno and Hasenauer 2016; Cornes et al. 2018). The continental and global databases of past climate data are often the products of spatial interpolation of instrumental time series from climate stations. Therefore, the precision of the interpolated data depends on the density of climate station data provided by individual countries. In the following section, we briefly review the existing approaches to model and predict climate conditions. 


\subsubsection{Climate Models}

Climate models are numerical representations of the Earth's climate system based on global patterns of physical processes, including chemical and biological components of the climate system, simulating the transfer of energy and materials through the system. Currently, there are a variety of models available from simple, simulating only a certain process in the atmosphere, to complex, simulating many processes of the climate system.

Global climate models (GCMs) are general circulation models, which were developed on general principles of fluid dynamics and thermodynamics (Stute et al. 2001). A crucial limitation of global models for their use in ecological modelling is the coarse spatial resolution. Therefore, regional climate models (RCMs) were developed by downscaling GCMs to the region of interest. The more recently developed RCMs have provided a tool to characterise past and future climates at various spatial scales (Rummukainen 2010).

\subsubsection{Climate Change Scenarios}

The intensifying greenhouse effect leads to global warming and to change in other climate characteristics on the Earth. The most serious consequences are changes in general atmospheric circulation, shifting in frontal and climate zones and the high speed of climate change, exceeding all previous climate changes at least tenfold. This is what scientists have learned from the mathematical modelling of the Earth climate system, where critical physical and chemical processes in the atmosphere and the oceans and physical processes associated with the cryosphere, biosphere and lithosphere were considered (IPCC 2014).

In 2000, the Intergovernmental Panel on Climate Change (IPCC) issued its Special Report on Emissions Scenarios (SRES) and introduced four scenario families to describe a range of possible future climate conditions. Each scenario (A1, A2, B1 and B2) was based on a complex relationship between the socioeconomic forces driving greenhouse gases and aerosol emissions (Nakicenovic et al. 2000). The SRES scenarios have been in use for more than a decade.

In 2009, a new set of scenarios was developed based on the concentration of greenhouse gases in the atmosphere in 2100 (Moss et al. 2010). These scenarios are known as Representative Concentration Pathways (RCPs). Each RCP indicates the amount of radiative forcing, expressed in watts per square metre, that would result from greenhouse gases in the atmosphere in 2100. These four RCPs were used for climate modelling in the IPCC Fifth Assessment Report (AR5) (IPCC 2014): RCP2.6 with radiative forcing peaking at approximately $3 \mathrm{~W} \mathrm{~m}^{-2}$, RCP4.5 at $4.5 \mathrm{~W} \mathrm{~m}^{-2}$, RCP6.0 at $6 \mathrm{~W} \mathrm{~m}^{-2}$ and RCP8.5 peaking at $8.5 \mathrm{~W} \mathrm{~m}^{-2}$, being the most pessimistic scenario at the time. 
As in the case of SRES, the GCM/RCM is used to derive data under different RCP scenarios (Jacob et al. 2014). The simulations from the climate models are then used as input to growth models, in some cases with a preceding statistical downscaling to account for topographic effects at a scale below $10 \mathrm{~km}$ and to match the grain size of forest models (Temperli et al. 2012; Seidl et al. 2019).

\subsection{Simulating Future Forest Growth in the Context of CSF}

Forest growth models are used to predict the development of trees, stands and forest ecosystems in the near or distant future, under various scenarios. Forest modelling science has developed from simple empirical yield models (YM), based on either single-time inventories or repeated empirical measurements and regression equations, to more complex empirical models (EM) and dendroclimatic models (DM) and to mechanistic models (PM), which describe physiological mechanisms and processes to predict forest growth. More complex empirical growth simulators (ES) and hybrid (semi-empirical) models (SES), which combine empirical regression equations with physiological processes, are better placed to be used to simulate future forest development than the simple YM and EM, because they often directly include growth sensitivity to climate. A range of growth models available include whole landscape or biome models, stand models, diameter distribution and size class models and individual-tree models (Burkhart and Tomé 2012a). The classification of forest growth models was presented in many studies (Porté and Bartelink 2002; Mäkelä et al. 2012; Fabrika and Pretzsch 2013; Fabrika et al. 2019). Growth models can be classified according to their ability to account for inter- and intraspecific competition and according to the sensitivity of simulated tree/stand growth to climate variation (Fig. 7.2). Tree-level (individual tree or gap/patch) ecophysiological models (the rightmost dark green box in Fig. 7.2) are believed to be most suited for simulations of forest development, because they combine causal effects of climate change and inter- and intraspecific competition (Rötzer et al. 2010; Seidl et al. 2012).

Simulations of forest development with forest growth models require input data, according to the spatial scale for which the prediction of future forest development is required (Fig. 7.3). Input data sources are reviewed in Sect. 7.4 in more detail.

Until recently, forest growth models (mainly ES) were used to predict biomass production and to test the effects of different management approaches and climate change scenarios. However, increasing requirements for a variety of ecosystem services as well as for sustainable forest management have raised the demands on models to expand the spectrum of outputs (Mäkelä et al. 2012; Temperli et al. 2020).

To allow assessment of CSF with modelling approaches, forest growth models must be able to simulate forest stand development under varying forest management alternatives (e.g. different silvicultural treatments) and policy strategies (e.g. 


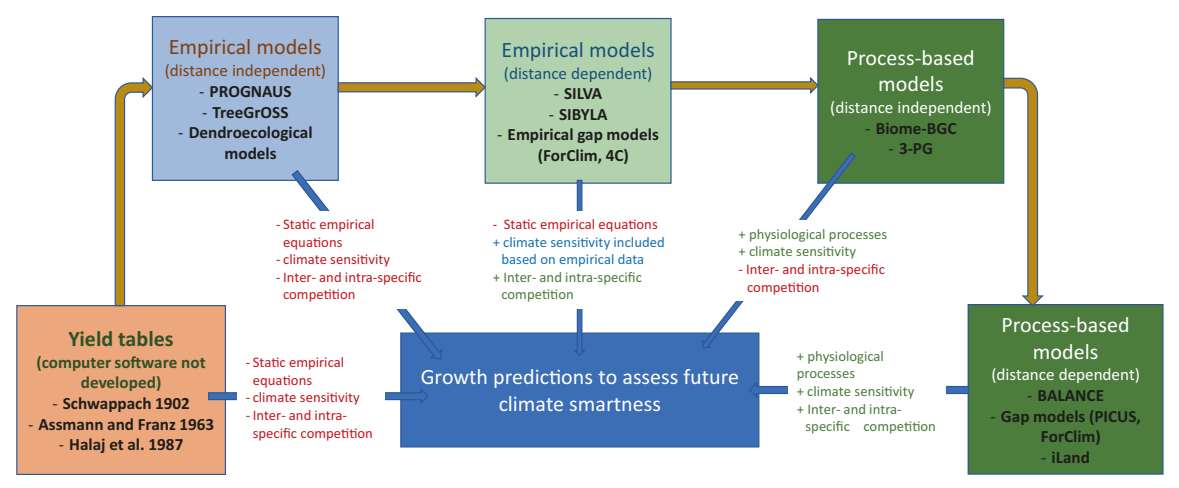

Fig. 7.2 Classification of forest growth models in the context of climate-smart forestry with some examples of existing models or groups of models for each class (in bold black letters). The brown arrow denotes increasing details on ecosystem processes implemented in models

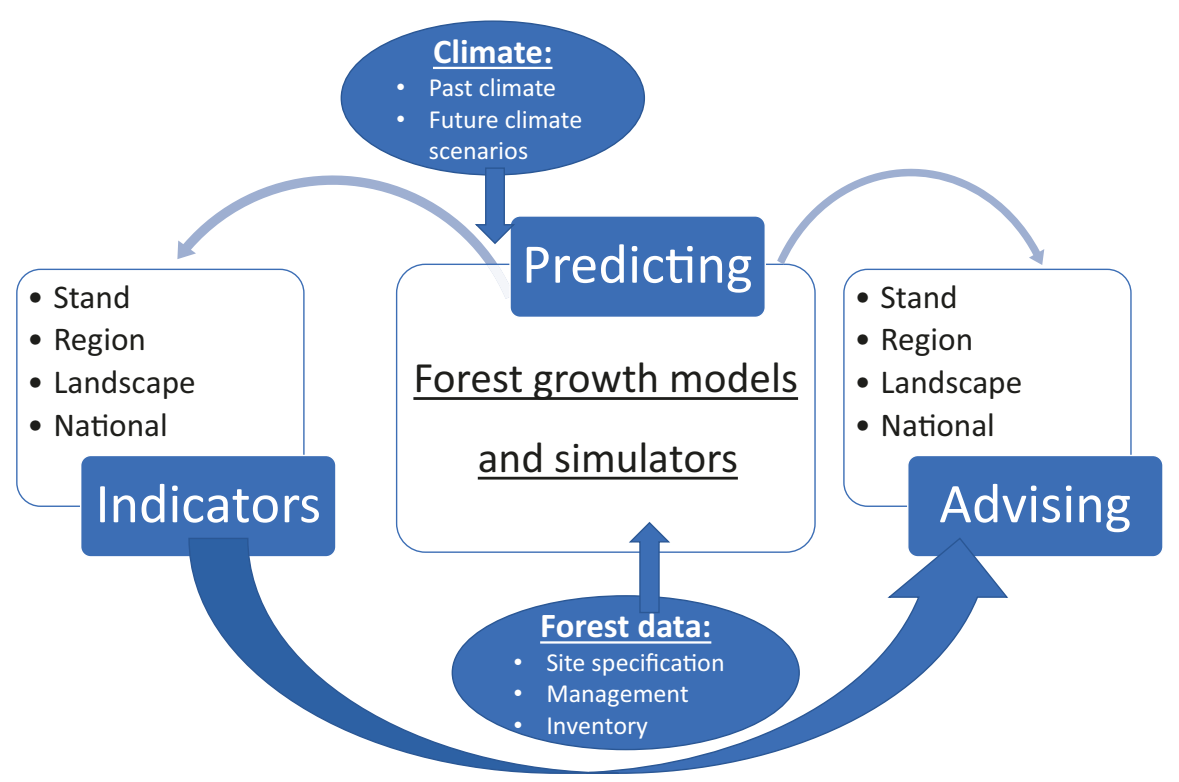

Fig. 7.3 Scheme of the process of predicting future growth and development of forest ecosystems and advising at different spatial scales

emission scenarios). Models should be able to simulate direct and indirect effects of different silvicultural treatments not only on tree growth rates (representing their potential to store carbon) but also on wood quality (the potential of timber to be used for substitution of carbon-intensive materials or fossil fuels) (e.g. Mäkelä et al. 2010).

Bowditch et al. (2020) selected a set of CSF indicators, by combining the panEuropean indicators for sustainable forest management (SFM) (FOREST EUROPE 
2015) with the ecosystem services defined by the European Environment Agency in the Common International Classification of Ecosystem Services (Haines-Young and Potschin 2018), to assess if the applied CSF practices are on track to meet the goals of forest adaptation and mitigation to climate change. Annex 7.1 resumes the ability of example growth models to address the indicators of CSF based on Bowditch et al. (2020). The models listed in the table represent individual groups following the classification provided above (Fig. 7.3).

\subsubsection{Empirical Growth Models}

Empirical models use correlation relationships translated into a set of regression equations to simulate tree and/or stand growth. Empirical models include YM, DM and ES.

\subsubsection{Yield Models}

YMs, experiencing more than 250 years of history, are the oldest models in forestry science and practice. They "predict" forest development over the rotation period or longer and are usually based on long-term monitoring or permanent research plots. They are based on regression functions derived from the empirical data and are often presented in the form of handy yield tables (which summarises expected yield tabulated by measurable stand characteristics, such as age, site index and stand density) to enable their use in forestry practice. Pretzsch (2009) and Fabrika and Pretzsch (2013) provided a comprehensive review of yield tables developed since the eighteenth century.

These models mainly rely on the classical assumption of the stationarity of site conditions (Vanclay and Skovsgaard 1997; Skovsgaard and Vanclay 2008) and thus are not capable of predicting forest growth under changing environmental conditions. They predict stand characteristics, such as stand height and diameter, standing volume (merchantable), stand density, etc., and do not consider inter-tree and interspecific competition when used to simulate the growth under different forest management. They use a species site index (top or mean stand height at a standard age, e.g. 100 years) based on height-age curves to consider site potentials to produce wood. In mixed forests, they are used to predict the growth of individual species and their predictions are subsequently combined to a stand level. An exception is the YM developed for mixed forests (Christmann 1949).

These models are, in many cases, well suited to estimate the current amount of wood in forests based on a few measurements but not to predict the future growth of tree species under scenarios of various environmental changes. 


\subsubsection{Empirical Growth Simulators}

ES have the second longest tradition in forest modelling after YM. Therefore, in the recent decades, these models began to be intensively used to forecast the development of the forest and to study the impact of changed conditions (environmental, economic, socio-economic) on the growth and structure of the forests (Sodtke et al. 2004). Compared to YMs, the range of conditions for ES application has been largely expanded. Their applications are no longer limited to monospecific and even-aged forests. ESs can model forest stands of various species, age spatial structures. Their ability to account for these forest characteristics depends on the spatial detail of modelling (population, class/cohort or individual) and how the model accounts for the spatial changes in environmental conditions due to inter-tree competition for resources (Fabrika and Pretzsch 2013). Based on the competition for resources, we recognise distance-independent models (Sterba 1995; Nagel 1996) and distance-dependent models (Hasenauer 1994; Pretzsch et al. 2002) (Fig. 7.3). Distance-independent models are biogroup-, ecosystem- or landscape-scale models, whereas distance-dependent models simulate individual trees and thus require spatial coordinates of trees in the stand. The emergence and development of ES made it possible to address the impact of different forest management on forest growth and structure (e.g. thinning) and thus eliminated the limitations of YM, i.e. their applicability only for a few methods of forest management. The range of applicable forest management variants is increasing from population through class/ cohort to individual-tree models and from distance-independent to distancedependent models (Fabrika et al. 2019). This advance in the modelling has opened the space for the use of models, if they are, at the same time, sensitive to climate, to assess the impact of climate change on forest growth and structure (Hlásny et al. 2011). However, an additional limitation related to the response of the increment in tree size to environmental conditions needed to be further addressed in EMs. First EMs used the phytocentric method to quantify site quality that affects the growth of trees and stands (Nagel 1999). However, the static nature of the site index (discussed in Sect. 7.3.1.1) is at odds with the principle of the forest's response to climate change. Therefore, models with a geocentric method (Kahn 1994) have been developed. The geocentric approach considers a direct response of the tree/stand growth to climatic and soil characteristics, for example, expressed by a direct regression model (Monserud and Sterba 1996) or by means of a dose-effect function (Kahn 1994). The link between environmental conditions and diameter/height/ volume increment is ensured through empirical (statistically derived) relationships. Such a modification of the models allows their use to assess the impact of climate change on forest growth and structure. Although the introduction of the geocentric approach has expanded the range of ES applications for environmental studies, the very nature of empirical models still limits their use. They cannot be used outside the range of environmental conditions for which they were developed. Therefore, to assess the climate smartness of forest management, statistical relationships should be replaced with causal relationships, which represents the shift from empirical to process-based (mechanistic) models. 


\subsubsection{Dendroecological Models}

Dendroecology refers to the use of annual tree rings and dendrochronological techniques to address questions in ecology (Fritts and Swetnam 1989). Tree rings are the products of multiple processes related to the energy, water, carbon and nutrient budget (Babst et al. 2014a). They represent a part of the above-ground carbon accumulation. Dendroecological models establish relationships between tree-ring measurements and environmental factors (Fritts 2001). Originally, dendrochronologists used the relationships between tree-ring formation and climate variance as a proxy to estimate climate variability in a distant past for which weather measurements did not exist. Recently, tree rings have been increasingly used by forest scientists to investigate and model the effects of climate on tree growth and to build empirical models to predict the future growth of forest tree species (Girardin et al. 2008; Chen et al. 2010).

Although tree rings represent only radial stem growth at a particular stem height, tree-ring data-based estimation of above-ground carbon sequestration has been found to be coherent with the net ecosystem productivity measured using eddy covariance techniques (Babst et al. 2014b). However, the contrasting results found in other studies dealing with tree-ring data (Rocha et al. 2006) suggest that there is often a problem with scaling from a tree stem to a forest ecosystem because of sampling bias and stand dynamics (Cherubini et al. 1998; Nehrbass-Ahles et al. 2014).

The developed models were often based on linear relationships between mean tree-ring width (TRW) chronologies and climate variables (Cook and Kairiukstis 1990; Fritts 2001; Dorado-Liñán et al. 2019). They did not consider changes in the relationships over time due to changes in the environment other than climate variation (Guiot et al. 2014). Such empirically-based models should not be used to predict the growth outside the period and the range of site characteristics for which they were developed. Therefore, process-based dendroecological models have been developed to reproduce the daily cellular development (Wilson and Howard 1968; Rauscher et al. 1990; Fritts et al. 1991; Tolwinski-Ward et al. 2011). The first dendroecological process-based model was the TRACH model (Fritts et al. 1991). More recently, the Vaganov-Shashkin (VS) model of tree-ring formation was developed (Vaganov et al. 2006). The VS model and its simplified version called the VS-light model (Tolwinski-Ward et al. 2011), which uses daily climatic input variables and more than 30 parameters for simulating secondary growth of xylem and anatomical features of annual rings, are now frequently used in dendroecological studies (e.g. Sánchez-Salguero et al. 2017).

Although some studies indicated the potential of empirical models developed from tree-ring data for predicting the future growth of forest trees (Dorado-Liñán et al. 2019), process-based models are currently preferred over EMs. However, the crucial role of tree-ring data is to inform vegetation models about long-term forest growth variability and disturbance regime from local to global scales (Babst et al. 2014a). Moreover, process-based models, in general, should be compared against regional and stand-level tree-ring data in shorter periods to avoid potentially biased estimations of net primary productivity by mechanistic models. 


\subsubsection{Process-Based Growth Models}

Unlike empirical model and dendroecological process-based models that focus only on tree-ring formation, PMs simulate physiological processes in the whole plant (photosynthesis, respiration, allocation, mortality, transpiration, translocation and nutrient uptake) and their interactions with processes in the atmosphere and soil. The models relate plant carbon budgets to environmental drivers, climatic variables and/or biogeochemical processes (Battaglia and Sands 1998). This enables PMs to simulate forest responses to changing environmental conditions (e.g. future climate change).

However, our understanding of individual processes differs, some being understood better than others. For example, carbon allocation, which has a critical role in forest adaptation to environmental changes, is often simplified due to insufficient knowledge on driving mechanisms (Merganičová et al. 2019). The other crucial uncertainties in PMs include mortality and regeneration (Mäkelä et al. 2000; Bugmann et al. 2019).

In contrast to EMs, PMs usually work at a finer temporal resolution, starting from less than a minute (Fontes et al. 2010; Pretzsch et al. 2015). Only a few process models, such as 3-PG, FORMIND or TRAGIC, use a coarser scale than 1 day (Hauhs et al. 1995; Köhler and Huth 1998; Forrester and Tang 2016). Many processbased models use different temporal resolutions for simulating different processes, e.g. carbon allocation is frequently simulated at a coarser scale than photosynthesis (Merganičová et al. 2019).

To incorporate physiological processes as realistically as possible, PMs use many physiological parameters as well as input stand and environmental variables. Environmental variables often include solar radiation, temperature, precipitation, wind speed and direction, vapour pressure deficit, nitrogen deposition, $\mathrm{CO}_{2}$ content in the atmosphere and available soil water content measured at fine temporal resolutions. Long-term, cost-effective and highly instrumented monitoring plots may provide such data, enabling key forest indicators to be modelled. Discussion on highly instrumented experimental plots is presented in Chaps. 10 and 16 of this book (respectively, Tognetti et al. 2021; Pappas et al. 2021). Several models are more simplistic and use only some of these variables and at a coarser temporal resolution (e.g. 3-PG, Landsberg and Waring 1997), whereas others are more complex requiring most of the variables at a finer scale (e.g. ANAFORE, Deckmyn et al. 2008, or FORCLIM, Bugmann 1996). The models range from biome-scale (e.g. Biome-BGC, Thornton et al. 2005) to individual-tree models (e.g. BALANCE, Rötzer et al. 2010).

Landscape dynamics or forest landscape models (LDM) are another group of PMs. The LDMs are based on the interaction of spatial patterns and ecological processes at various spatio-temporal scales. They usually simulate forest dynamics at a site scale (up to $300 \mathrm{ha}$ ) and landscape processes at a larger scale (He 2008; Shifley et al. 2017). For example, the process-based model of forest landscape dynamics iLand (Seidl et al. 2012) simulates forest landscape dynamics via 
modelling spatially explicit resource availability at the landscape scale and integrating local resource competition and physiological resource use. Moreover, it simulates spatial and temporal interactions of vegetation and disturbance agents, which place this model among the most complex models from the point of simulated landscape dynamics. Another widely used LDM in Europe is LandClim (Schumacher et al. 2004). It basically uses a gap-model approach to simulate forest dynamics in individual grid cells of $25 \times 25 \mathrm{~m}$ of a landscape wide up to $50 \mathrm{~km}^{2}$ and accounts for spatial processes, such as wind, fire disturbance, bark beetle, seed dispersal and forest management. Recent applications include estimates of adaptive management effects on forest ecosystem service provision (Temperli et al. 2012), reconstruction of species range shifts in the Holocene (Henne et al. 2013), analyses of disturbance interaction with climate change (Temperli et al. 2015) and biodiversity (Schuler et al. 2019). The FLM TreeMig is also raster based but can be applied from the watershed to the continental scale (Lischke et al. 2006). While it primarily focuses on tree migration under climate drivers (Meier et al. 2012; Scherrer et al. 2020), it has also been applied to assess avalanche-forest interactions (Zurbriggen et al. 2014). Remote sensing technologies may contribute with spatially explicit time series of vegetation traits to estimate temporal changes in CSF indicators at the landscape scale as well as to serve as input for models. Benefits and challenges of remote sensing for monitoring forest ecosystems are presented in Chaps. 11 and 16 of this book (respectively, Torresan et al. 2021; Pappas et al. 2021).

Reliability of growth predictions using PMs depends on various factors, including the spatio-temporal scale of the predictions, level of details available to calibrate and validate the models, etc. The scale and detail of various types of forest monitoring data strongly influence the reliability of simulations. In this regard, new approaches include, for example, model-data fusion with Bayesian inference, which have the potential to strongly reduce the prediction biases and increase their reliability (Trotsiuk et al. 2020).

PMs are thus well placed to address the CSF and support decisions in adaptation and mitigation strategies, because they consider species sensitivity to environmental conditions via physiological processes. PMs can be used to test different scenarios of future environmental conditions. However, there are some components that still need to be developed or improved in PMs to predict future forest growth and landscape dynamics more realistically. These include, for example, intra- and interspecific competition/facilitation, tree mortality, deadwood, natural regeneration and carbon allocation to different tree components. In particular, below-ground carbon allocation needs to be further validated in most of the PMs and analysed with greater accuracy, since it can strongly affect the ecosystem response to climate change. Management is often not simulated by PMs in detail - particularly in the group of models that do not account for the inter-tree competitive interactions in the stand. In such cases, simplified rules need to be applied to test the impact of different management scenarios, e.g. the proportion of biomass extracted (Merganičová et al. 2005). 


\subsubsection{Considering Environmental Conditions in Growth Models}

In the case of YMs, environmental conditions are indirectly considered by the site index. Site index usually refers to the mean (Halaj and Petráš 1998) or dominant (Burkhart and Tomé 2012b) stand height at a standard age (e.g. 100 years). However, YMs consider that site index is a temporarily static parameter that represents site conditions at the time of data collection. Once used for predictions outside the conditions and region of empirical data, small to large systematic errors can be expected, and reliability of predictions is strongly limited. Recently, advanced methods were proposed to develop dynamic site index models (Socha and Tymińska-Czabańska 2019), which consider the changes of site index due to changing environmental conditions.

In ESs and SESs, site conditions affect tree or forest growth potential defined by a growth function (Burkhart and Tomé 2012c) using a modifier based on, for example, ecological site classification (Pretzsch et al. 2002). Among the ESs that apply this growth reduction approach are SILVA (Pretzsch et al. 2002) and SIBYLA (Fabrika 2005). Other ESs use explicit empirical relationships between climate predictors (temperature, precipitation, drought indices) and growth, regeneration and mortality processes to simulate forest development (Stadelmann et al. 2019; Zell et al. 2019).

Unlike YMs and ESs, PMs simulate physiological mechanisms that are directly affected by environmental conditions. PMs are thus more reliable and better suited to simulate future growth of forests under alternative climate change scenarios under the assumption that processes are correctly described, whereas ESs are confined to the climatic space that is represented by the data they have been parameterised with.

\subsubsection{Integrating the Effects of Species Mixture into Growth Models}

Recently, a strong research activity with the aim to explore how species interactions influence wood and biomass production (Pretzsch and Schütze 2009, 2015; Rötzer et al. 2009; Pretzsch et al. 2010; Jucker et al. 2014; Toïgo et al. 2015) and how to improve forest multifunctionality (van der Plas et al. 2016) has been ongoing. According to Pretzsch et al. (2015) and Bravo et al. (2019), one of the following four principles can be used to predict the growth of mixed-species forests: (1) by applying weighted means of monocultures, (2) multipliers, (3) species-specific growing space competition indices or (4) process-based representation of mixing effects. Most common single-species YM can be used to predict growth in mixedspecies forests by simple weighted means of species growth predicted in 
monocultures. This approach does not consider interspecific competition, and thus, it is less suitable to simulate the future growth of mixed-species forests. Individualbased empirical growth simulators often include inter-tree and interspecific interactions by means of various distance-dependent competition indices (Pretzsch et al. 2002, 2015; Fabrika 2005). The use of empirically based multipliers or more advanced competition indices used in ES often assumes that interactions do not change over time. However, a few competition indices use tree dimensions in the calculation and thus consider competition changes over time. PMs have the potential to overcome the shortcomings of ES by modelling species interactions in a mechanistic way. PMs differ in which processes are considered to be affected by species-mixing effects, i.e. radiation, water, phenology, nutrients and structure (Pretzsch et al. 2015). However, only a few PMs and LDMs consider species interactions in most of the processes to simulate the growth of mixed forests more realistically (Rötzer et al. 2010; Seidl et al. 2012; Temperli et al. 2012; Forrester and Tang 2016; Huber et al. 2018). Also, in this case, it is challenging to better understand how the species composition affects carbon allocation within the tree and among the trees belonging to different species and social positions, and its comprehension would dramatically improve the prediction ability of PMs.

\subsubsection{Integrating Silvicultural Prescriptions and the Induced Treatment Responses into Growth Models}

Forest management, specifically silvicultural treatments applied over the rotation period, can modify species composition and canopy structure, which in turn can influence forest response to environmental change, including direct effects of warming and drying or other disturbances caused by various factors, such as wind, snow, game and ice (Seidl et al. 2011; Mausolf et al. 2018). The effects of silvicultural interventions and past natural and human-induced perturbations should be correctly considered in forest growth simulation studies, especially in the case of intensively managed European forests (Spiecker 2003; Fontes et al. 2010). Silvicultural techniques influence not only the productivity (and so the carbon sequestration) of the forest stand but also carbon allocation among the tree and stand components, forest vertical and horizontal structure, crown morphology, forest stability and vitality, which alter the resistance of forest to various types of disturbances (Noormets et al. 2015). For example, "heavy thinning from below" applied in some European countries removes all suppressed trees and keeps dominant trees that are all directly exposed to macroclimate (Bosela et al. 2016c). On the other hand, vertically more diversified forests after "thinning from above" may be more resistant under predicted future climate change conditions. Applied silvicultural treatments, including different regeneration methods, have a significant role in creating more complex forests that are expected to be more resistant and resilient to changes in environmental conditions and natural disturbances (O'Hara 2006; Puettmann 2011; O'Hara and 
Ramage 2013; Lafond et al. 2014; Fahey et al. 2018). Forest microclimate, altered by different silvicultural treatments, will probably have a crucial role in buffering extreme weather events in the future (Zellweger et al. 2020).

Several models consider silvicultural treatments as a very important component of future growth predictions (Fontes et al. 2010; Fabrika et al. 2018). The most common management intervention employed in growth models is thinning, which can vary by type, intensity and timing. Different types of thinning are implemented mostly in individual-tree process-based models, functional-structural plant models, distance-dependent and distance-independent empirical tree models, tree and cohort gap models or distribution stand models (Fabrika et al. 2018). Other management prescriptions rather rarely applied in growth models are early stand treatments (weeding, cleaning), fertilisation often combined with thinning and harvesting (Weiskittel et al. 2011).

Up to now, less than one-third of all existing growth models consider speciesmixing effects and can be directly applied to mixed forests (Pretzsch et al. 2015). The present tendency in silvicultural prescriptions to convert monospecific to multispecies stands or establish new mixed forests is very much favoured, considering matching species composition to site conditions, and requires the development and implementation of appropriate silvicultural strategies for mixtures into growth models (Bravo et al. 2019).

Despite the importance of silvicultural treatments on stand productivity and climate sensitivity of tree species, forest growth models are not always capable of simulating the effects at individual tree level. This limited capacity is because some of the models operate at a stand or biome level and thus are unable to consider interand intraspecific competition or facilitation (Jucker et al. 2014). Stand- and biomescale distance-independent models can simulate the growth under varying stand densities (Horemans et al. 2016), whereas individual-tree distance-dependent ESs/ SESs and PMs are well placed to simulate the growth of individual trees and forest stands under different silvicultural treatments and/or forest disturbances (Pretzsch et al. 2002; Fabrika 2005; Seidl et al. 2012; Mina et al. 2017). Other constraints of the wider application of silvicultural methods in growth models include the quality and quantity of experimental data available and appropriate determination of temporal resolution (Weiskittel et al. 2011).

Nevertheless, much effort needs to be invested to improve the existing forest growth models to include an entire portfolio of silvicultural strategies and forest management that would address global climate change (D'Amato et al. 2011).

\subsubsection{Effects of Genetic Structure on Forest Growth}

Postglacial migrations have altered the genetic diversity of organisms (Hewitt 2004). Evidence has suggested that the populations in refugial areas are typically genetically more diverse and the allelic richness may gradually decline along the 
migration routes (Hewitt 2000; Petit et al. 2003). A certain level of genetic diversity is required to allow populations to adapt to changing conditions (Howe et al. 2003). A recent study showed the impact of postglacial migration on genetic diversity of European silver fir, Abies alba Mill. (Liepelt et al. 2009), which might have had strong effects on the growth and climate responses of the species (Bosela et al. 2016a). Climate-driven natural selection also leads to local adaptation if the climate remains static over at least one tree generation. It may be questioned whether this was ever the case in any tree species' history since the last glaciation in Europe. Tree populations usually exhibit moderate to strong local adaptation; however, fast environmental change may cause local populations experience conditions to which they are not yet adapted (Howe et al. 2003; Wang et al. 2010). Therefore, the higher the genetic diversity is at the population level, the more chance for populations to adapt to the changing environmental conditions (Howe et al. 2003). Consequently, recommendations have stressed the importance of high genetic variability of forest plant material for uncertain futures (Eriksson et al. 1993; Yousefpour et al. 2017). Strong selection, especially among seedlings, would play a crucial role for local selection in natural forests, and varying adaptation effects would recur and act differently in time and space (at different locations and on each tree generation). How far such effects also come to bear on plant material raised under optimal conditions in nurseries and planted under growth-promoting forest management measures remains an open question (Namkoong 1998). Co-occurring tree species can develop quite different adaptive strategies under identical environmental conditions. Contrasting genecological patterns reported for spruce and fir (strong climaterelated differentiation in spruce vs. modest differentiation in fir) suggested that spruce can be considered an adaptive specialist while fir is more an adaptive generalist (Frank et al. 2017).

Strong latitudinal clines in the bud burst of tree species (Kramer et al. 2015), which depends on critical temperature sums specific to the climate a provenance is adapted to, and the effects of genetic diversity on tree growth (Bosela et al. 2016a) suggest (successful) genetic adaptations to local environmental conditions in the standing tree generation. However, the bud burst response of, e.g. European beech (Fagus sylvatica L.) to temperature sums proved to be plastic (Kramer et al. 2017), which further complicates the evaluation of the issue. Despite that the effects of intraspecific genetic variability on the responses to local climate conditions were ascertained (Neale and Wheeler 2019), still only a very few forest growth models address this aspect (Kramer et al. 2015; Berzaghi et al. 2020). It is important to stress that strongest selection/adaptation effects are experienced by tree populations in the seedling stage (when individuals are most vulnerable to extreme conditions) or in the event of catastrophic disturbances that kill the less resilient individuals. Ignoring the above effects in predicting future adaptive responses of tree species may under- or overestimate the potential of species under changing environmental conditions. Moreover, phenotypic plasticity and adaptive capacity of tree species may be significantly modified by epigenetic variation (Bräutigam et al. 2013). 


\subsection{Source of Data to Parameterise, Calibrate and Validate Growth Models}

In this section, we review different sources of forest data, including national and stand-wise forest inventories, long-term research plots, eddy covariance system, dendrochronological networks (e.g. ITRB), climate and soil databases and remotely sensed data that can be acquired or are available to be used for forest growth models.

\subsubsection{National Forest Inventory}

It was as early as in the 1910s and 1920s when the European Nordic countries, namely, Norway, Sweden and Finland, launched the first sample-based national forest inventories (NFIs) as a response to the increasing importance of forests and wood for their economy (Vidal et al. 2016a). However, sample-based inventories were not initiated in the rest of Europe until after World War II. Since then, their importance has increased, and the country-scale inventories were launched in France (1958), Austria, Spain, Portugal and Greece (1960s), followed by Switzerland, Italy, Germany (1980s) and other countries. Nowadays, almost all countries in Europe conduct their NFI (Vidal et al. 2016a).

NFIs represent the main source of information about the state and changes of wood resources primarily at a national scale, but in some cases also at a regional scale. However, varying sampling designs among the European countries due to varying policy needs in the past limited the use of European NFIs for international reporting. Recent international activities were successful in harmonising the outputs of the European NFIs at European scale (Vidal et al. 2008, 2016a, b; Bosela et al. 2016b; Fischer et al. 2016; Gschwantner et al. 2016; Alberdi et al. 2020).

NFIs are valuable sources of data for parameterisation and calibration of forest growth models and simulators, because they often provide repeated measurements, representative of a region, landscape and country (McCullagh et al. 2017). They cover a broad range of site conditions, where tree species grow. Data from NFIs have been successfully used to calibrate and validate empirical growth simulators (Fabrika 2005; McCullagh et al. 2017). In Switzerland, the NFI-based forest management scenario model MASSIMO is, among others, successfully used to simulate future harvesting potentials, forest-related carbon budgets and forest reference levels used in greenhouse gas reporting (Stadelmann et al. 2019). In Germany, the NFI-based forest model WEHAM is used to evaluate the sustainability of potential future forest policy scenarios (Seintsch et al. 2017). Similarly, the Câldis system was recently used to evaluate climate-smart management scenarios in terms of standing biomass and carbon as well as soil carbon based on the data of the Austrian NFI (Jandl et al. 2018). NFI data were also used to parameterise or calibrate physiological forest development models (van Oijen et al. 2013; Gutsch et al. 2018; Minunno et al. 2019). 
Recently, NFI data of 23 European countries have been used to prepare future projections of the forest growing stock, above-ground carbon and harvesting until 2040 (Vauhkonen et al. 2019). The European Forest Dynamics Model (EFDM) was parameterised using NFI data, and future development of forest resources was simulated under business-as-usual forest management. Further, the large-scale European Forest Information Scenario model (EFISCEN) (Schelhaas et al. 2007) uses data of European NFIs and has been applied to evaluate the development of forest resources in the future under various management scenarios (Verkerk et al. 2011). These modelling activities suggest that European NFIs are suitable to serve the increasing information demands from national to international levels. As they are statistically sound and sufficiently cover the European forest area, NFIs can become the main source of data to aid in sustaining the resilience and climate smartness of the European mountain forests. However, the shortcoming of NFI data is that stand history is not known, and extreme densities and treatments are often insufficiently represented, although these are of special importance for model parameterisation and evaluation. The strength and limitation of NFI-derived CSF indicators, as well as an example of their application in two case studies, are presented in Chap. 4 of this book (Temperli et al. 2021).

\subsubsection{Stand-Wise Forest Inventory}

Stand-wise inventory, or inventory by compartments, is the assessment of wood resources of the forest stand defined as "geographically contiguous parcels of land whose site type and growing stock is homogenous" (Koivuniemi and Korhonen 2006). The first stand-wise forest inventories were often local and conducted by timber producers to estimate timber resources (Tomppo et al. 2010). For Central and Eastern European countries (especially the former socialistic countries with centrally planned economy), it has been typical to collect forest data at a stand level for management planning. State administration used these data to strictly regulate the use of forest resources at stand and forest district levels. In many Central-Eastern European countries (including the Czech Republic, Slovakia, Romania, Poland, Slovenia, etc.), stand-level inventories continue to be the main source of data for strategic management planning and regulation, despite the fact that the countries have already launched their sample-based NFIs. However, stand-wise inventory data are not available in most European countries. Moreover, stand-wise inventories are often conducted as surveys of forest managers and include expert assessments of forest characteristics, such as species composition, of unknown or limited precision, which strongly limits their use for scientific investigations (Grīnvalds 2014). Stand-wise inventory data are also limited in the spectrum of provided variables. They often only include mean stand variables, such as mean stand diameter and height, growing stock and stand density. The stand (compartment) area largely varies and often changes over time, which also limits the use of these data for temporal studies. 


\subsubsection{Long-Term Research and Monitoring Plots}

Long-term research or monitoring plots are a unique source of data that can be used to either build empirical models or to calibrate and validate available growth models and simulators (Pretzsch et al. 2014; Pretzsch 2020). Compared to tree-ring data, long-term plots usually include mortality data and thus provide information on the true development of forest stands. The spectrum of variables assessed and measured in the plots depends on the aims of monitoring but is often reduced to dendrometric characteristics, which limits their use for assessing the indicators of SFM and CSF. Long-term monitoring plots often include only simple diameter and height measurements, because volume stock estimation was the main purpose of establishing such plots in the past, and thus bring uncertainty when scaling to estimations of biomass and carbon stocks and fluxes. However, the European network of forest condition monitoring plots (International Co-operative Programme on Assessment and Monitoring of Air Pollution Effects on Forests, ICP Forests) provide an example of the long-term monitoring plots (from national to European scales) that go beyond the measurement of basic dendrometric characteristics (Michel et al. 2019). The biggest advantages of long-term monitoring plots are the long time period they cover (often several decades and in few cases more than 100 years) and the known management treatments. In an actual example, such data were used for estimating parameters of the process-based 3-PG model (Landsberg and Waring 1997) in conjunction with other data sources such as NFI data (Trotsiuk et al. 2020). Zell (2018) used data from long-term experimental forest management plots to parameterise an empirical climate-sensitive stand development model that includes an empirical management module. Thanks to long-term data, the capacity of forest gap-models to simulate accurate forest management prescriptions has greatly increased over the past decade (Rasche et al. 2011; Mina et al. 2017). A shortcoming of long-term plots is their uneven spatial distribution, covering only a small portion of the range of site conditions and only a few tree species. These include mostly productive sites and commercially interesting tree species, for studying the growth of which longterm plots have historically been set up. Moreover, monitoring plots that span across centuries are scarce and missing for most regions. However, establishing long-term monitoring plots across the range of site conditions is crucial to calibrate and validate growth simulators under changing climatic conditions and to support climatesmart forest management decision-making (Thrippleton et al. 2020). In Chap. 5 (Pretzsch et al. 2021), the design of a smart network of observational forest plots across European mountain regions is described, and a discussion on their relevance for monitoring growth patterns in monospecific European beech and mixed-species stands of Norway spruce, European beech and silver fir is provided. 


\subsubsection{Eddy Covariance Measurements}

The eddy covariance (EC) technique is an atmospheric measurement technique based on measuring vertical turbulent fluxes within atmospheric boundary layers. It is one of the most appropriate ways to measure local turbulent fluxes of $\mathrm{CO}_{2}$ (Wang et al. 2009). The technique is used to estimate seasonal fluctuations in carbon exchange between the forest and the atmosphere (Baldocchi 2003). This technique has been successfully used to estimate the net ecosystem productivity (NEP). EC measurements are often used for calibration and validation of NEP estimated by growth simulators (Kramer et al. 2002; Mo et al. 2008; Meyer et al. 2018). However, using the EC technique (but not only EC) includes two potential sources of uncertainty: measurement error and representativeness error (Lasslop et al. 2008; Youhua et al. 2016). Measurement error can be minimised by, for example, the calibration of the instruments. However, representativeness error depends on surface roughness and thermal stability, which further depends on the vegetation heterogeneity (Youhua et al. 2016). EC measurements are more accurate when the atmospheric conditions are steady, the terrain is flat and the surrounding vegetation is homogeneous (Baldocchi 2003). Hence, in the mountainous areas, i.e. in highly complex terrain, and in forests strongly affected by natural disturbances (e.g. fire, diseases, insect infestation), the precision of EC estimates of NEP strongly decreases. The more complicated orography and vegetation heterogeneity were likely the reason for different findings from nearly no link to the high correlation between biometric data and EC measurements (Rocha et al. 2006; Zweifel et al. 2010; Babst et al. 2014b). The distance between the forest under study and the nearest EC tower is another factor affecting the coherence between biometric and EC data (Babst et al. $2014 \mathrm{~b}$ ). A recent study based on a $5 \mathrm{~km} \times 5 \mathrm{~km}$ gridded EC measurements revealed large variability in the representativeness of single EC towers to estimate NEP (Youhua et al. 2016).

\subsubsection{Remote and Proximal Sensing}

Remotely sensed data, such as Landsat or Moderate Resolution Imaging Spectroradiometer (MODIS) satellite imagery, are increasingly used to estimate gross or net primary productivity (GPP, NPP, Neumann et al. 2016) and NEP or to derive vegetation indices further used in large-scale ecological studies, including the characterisation of forest disturbance regimes (Yuan et al. 2010; Jin and Eklundh 2014; Liang et al. 2015; Hart et al. 2017; Liu et al. 2018; Yang et al. 2020). Lightuse efficiency (LUE), defined as the amount of carbon produced per unit of absorbed 
photosynthetically active radiation (APAR), has been successfully used to quantify the dynamics in GPP. The models to estimate LUE, and therefore GPP, are usually based on normalised difference vegetation index (NDVI), photosynthetically active radiation (PAR), fraction of PAR, air temperature, moisture and other environmental conditions (Yuan et al. 2010). There are, however, various definitions of LUE used in developing LUE models, which have implications for the estimation of forest productivity (Gitelson and Gamon 2015). Ecosystem respiration (ER) is an essential component of water and energy budgets and is used to estimate NPP of forest ecosystems by its subtracting from GPP. It is, however, the most difficult component to estimate because of the heterogeneity of the landscape, soil properties and topography, among other factors (Yuan et al. 2010; Zhang et al. 2016). NDVI is a remotely sensed vegetation index frequently used to assess leaf phenology or changes in the canopy due to disturbances, such as bark beetle outbreak or wind storms (Jönsson et al. 2009; Meddens et al. 2013; Jin and Eklundh 2014). Although it is popular because of its robustness against noise, in some forest types, the index is too sensitive to snow cover and much less sensitive to growth of close-canopy forests (Jönsson et al. 2009). Canopy nitrogen content and chlorophyll lightabsorbance variables, used as indices to nutrient cycling and maximum photosynthetic capacity, can be estimated using both aerial and satellite optical hyperspectral imagery. Variables, such as above-ground tree height and vertical and horizontal distribution of tree crowns, used for the model parameterisation, can be computed using light detection and ranging (LiDAR) data and interferometric synthetic aperture radar (SAR). Other vegetation indices used in ecological studies include the enhanced vegetation index (EVI), normalized difference water index (NDWI), wide dynamic range vegetation index (WDRVI), phenology index (PI) and leaf area index (LAI). To obtain the remotely sensed data, the MODIS instrument aboard the Terra satellite is often used. MODIS is viewing the entire Earth's surface every 1 to 2 days and acquires data in 36 spectral bands, or groups of wavelengths. The spatial resolution of MODIS images is $250 \mathrm{~m}$ (bands 1-2), $500 \mathrm{~m}$ (bands 3-7) and $1000 \mathrm{~m}$ (bands 8-36). To increase the spatial resolution of MODIS-derived indices, a combination of MODIS and Landsat time series (available at finer $30 \mathrm{~m}$ resolution) provides a solution (Yang et al. 2020). Another promising remote sensing-based data sources are the Sentinel-1 and Sentinel-2 SAR data that can be collected independently from daylight or weather conditions and were recently used for rapid detection of windthrows (Frampton et al. 2013; Rüetschi et al. 2019).

There are various models able to utilise remote sensing data in different ways, but the satellite-driven version of the 3-PG model (Physiological Principles in Predicting Growth), developed by Landsberg and Waring 1997 and Waring et al. 2010 is probably the most known and used. The physiological variables used in the model can be estimated from remote-sensing measurements of factors that influence those variables. In the model, GPP is ultimately a function of the APAR and the canopy quantum use efficiency. 
It is worth mentioning that recent data assimilation (DA) techniques have been used to estimate forest stand data by sequentially combining remote sensing-based estimates of forest variables with predictions from growth models (Nyström et al. 2015). DA provides a way of blending the monitoring properties of remotely sensed data with the predictive and explanatory abilities of forest growth models (Huang et al. 2019). Input to the data assimilation may be canopy height models, obtained from airborne laser scanning (ALS) data or from image matching of digital aerial images at different time points during the growth season. With this approach, the prior forecast is updated to the posterior forecast when a new estimate is considered. This kind of approach needs modification of the existing growth models that would allow data assimilation and also requires the possibility to interrupt the model simulations before the end and use remote sensing data to update specific characteristics.

\subsubsection{Tree-Ring Time Series}

Annually resolved TRW series represent a valuable source of information on past growth dynamics of individual trees and forests (Babst et al. 2018, 2019; Klesse et al. 2018). Over the past century, TRW data have been collected across the globe for many different purposes, and a high portion of these data has been archived in the International Tree-Ring Data Bank (ITRDB) managed by Paleoclimatology Team of National Centers for Environmental Information and the World Data System for Paleoclimatology. ITRDB now includes TRW series from over 4000 sites and six continents. Tree-ring networks were frequently used to reconstruct past climate as well as to investigate responses of forest trees to variation in environmental characteristics to assess species vulnerability to changing conditions (Babst et al. 2013). Recently, TRW data have been successfully applied to predict future forest growth and climate responses (Charney et al. 2016; Dorado-Liñán et al. 2019). TRW data have also been used to reconstruct regimes of windthrow, bark beetle, storm and other disturbance regimes (Veblen et al. 1994; Svoboda et al. 2014). Explaining relationships between climate and disturbance dynamics (Hart et al. 2014) forms the basis to parameterise models of disturbance dynamics under climate change (Temperli et al. 2015; Thom et al. 2017). However, using TRW data for detecting long-term growth trends and species climate responses must follow purpose-oriented sampling designs (Nehrbass-Ahles et al. 2014) and appropriate detrending methods (Peters et al. 2015) to minimise potential prediction biases (Klesse et al. 2018). 


\subsection{Conclusions and Perspectives}

Expected rapid climate change will likely challenge the adaptation capacity of many forest ecosystems. Forest growth models represent a promising tool to predict the effects of different climate change scenarios on the growth of individual trees and forest stands as well as the future distribution of forest tree species under changing conditions and thus to support forest managers and policymakers in developing long-term strategies. Available forest growth models largely differ from each other in many ways due to which they provide a large range of future growth estimates. A multi-model averaging technique has been found a good way to avoid biased estimates of single models due to shortcomings of individual modelling approaches (Picard et al. 2012; Hlásny et al. 2014; Dormann et al. 2018). Although modelling the relationships between forest production and future climate is complex and intrinsically uncertain, forest growth models may help to guide climate-smart strategies aimed at overcoming mitigation, adaptation and production gaps. For example, synergies and trade-offs between biodiversity conservation and timber production can be assessed, and user-friendly interactive decision support tools can be developed, ensuring that all stakeholders envisage the risks of adapting their management strategies to changes in climate and society and anticipate the consequences of environmental disturbances.

Past constraints that limited the capacity to model forest dynamics, such as the availability of data for model calibration and validation, the computing capacity, the model applicability to real-world problems and the ability to integrate biological, social and economic drivers of change, have become less restrictive. For this, the role of models for predicting forest growth and yield under changing environments is now central in applied decision-making. For that, to ensure their role, great attention is required to evaluate the performance, to expand the driver of changes and to incorporate variables as input social and economic trends and needs.

Acknowledgements We would like to thank Laura Dobor, Sonja Vospernik and Thomas Ledermann for their valuable information regarding the ability of iLand and PROGNAUS models to address the indicators of climate-smart forestry. Michal Bošel'a received support from the Slovak Research and Development Agency via the grants No. APVV-15-0265 and APVV-19-0183. Katarína Merganičová was supported by the grant "EVA4.0", No. CZ.02.1.01/0.0/0.0/16_01 9/0000803, financed by OP Research, Development and Education, and the project "Scientific support of climate change adaptation in agriculture and mitigation of soil degradation" (ITMS2014 + 313011 W580), supported by the Integrated Infrastructure Operational Programme funded by the European Regional Development Fund. Ilona Mészáros was supported by grant No. NKFI-125652 from the National Research, Development, and Innovation Office, Hungary. In memory of Giustino Tonon, a co-author of this chapter, who had passed away prior to the publication of the book. 


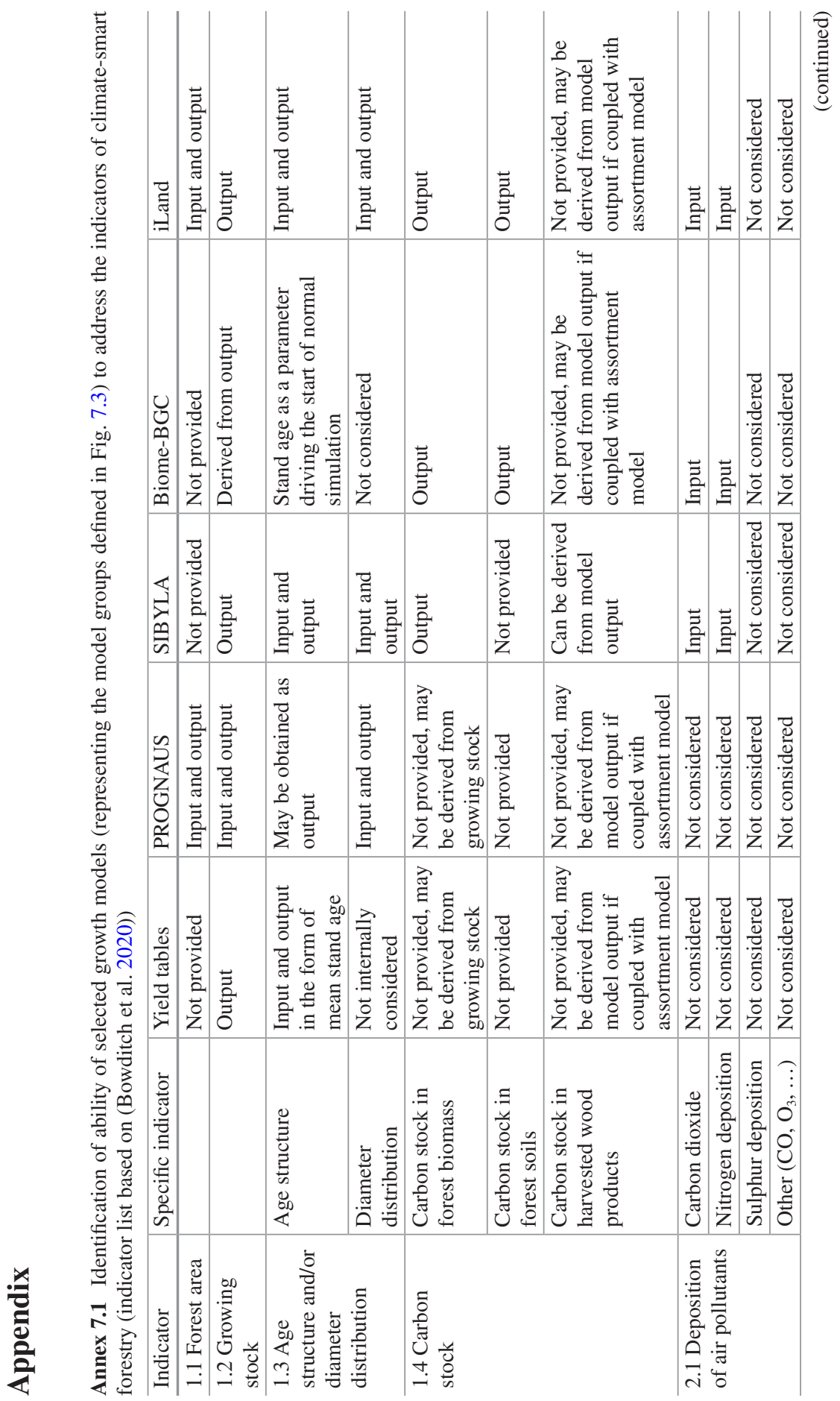




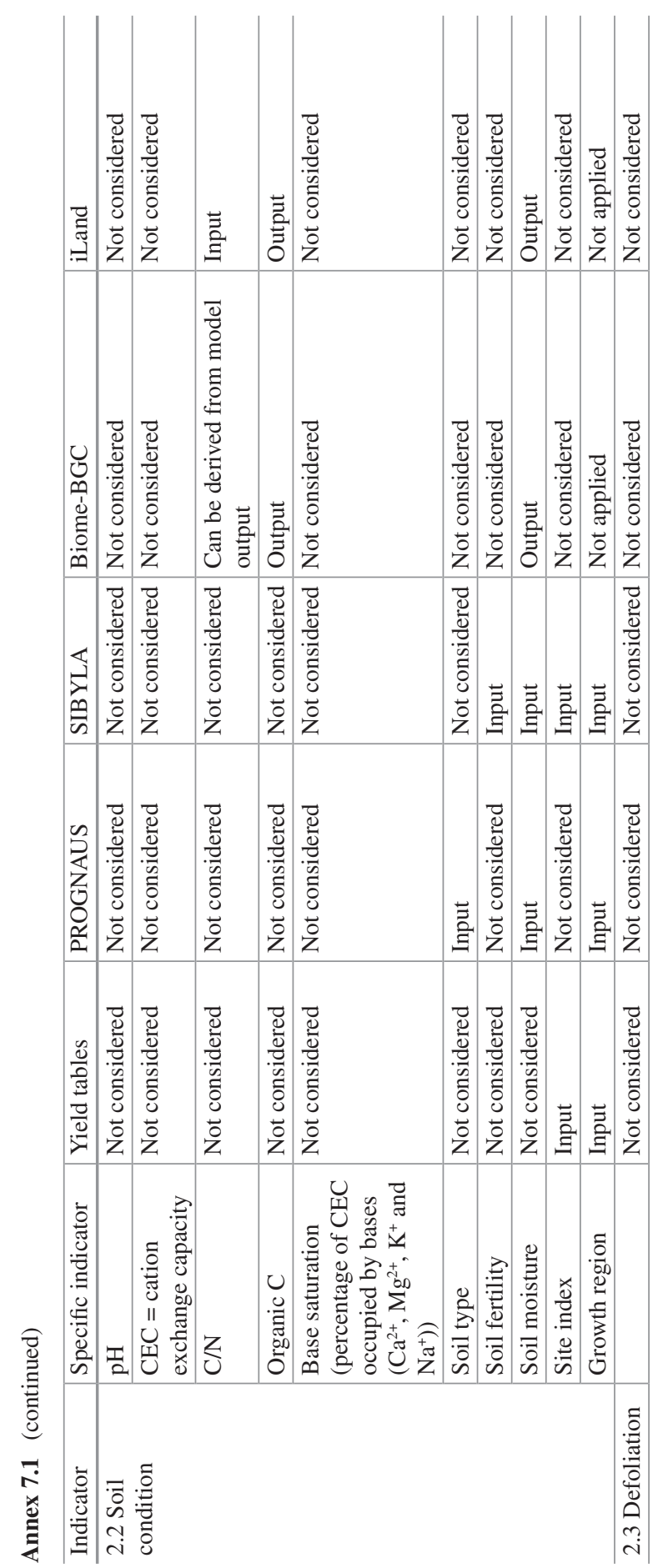




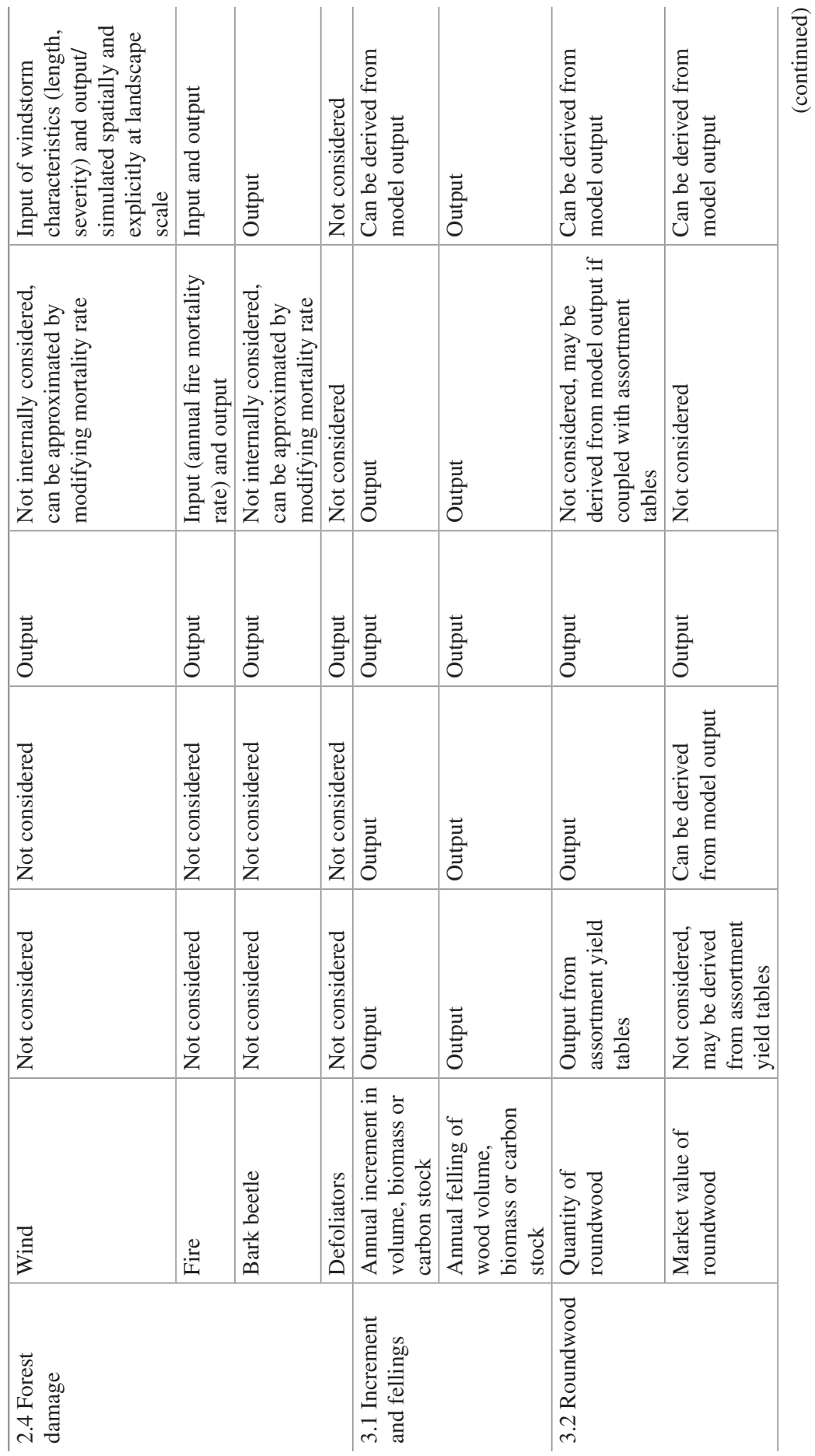




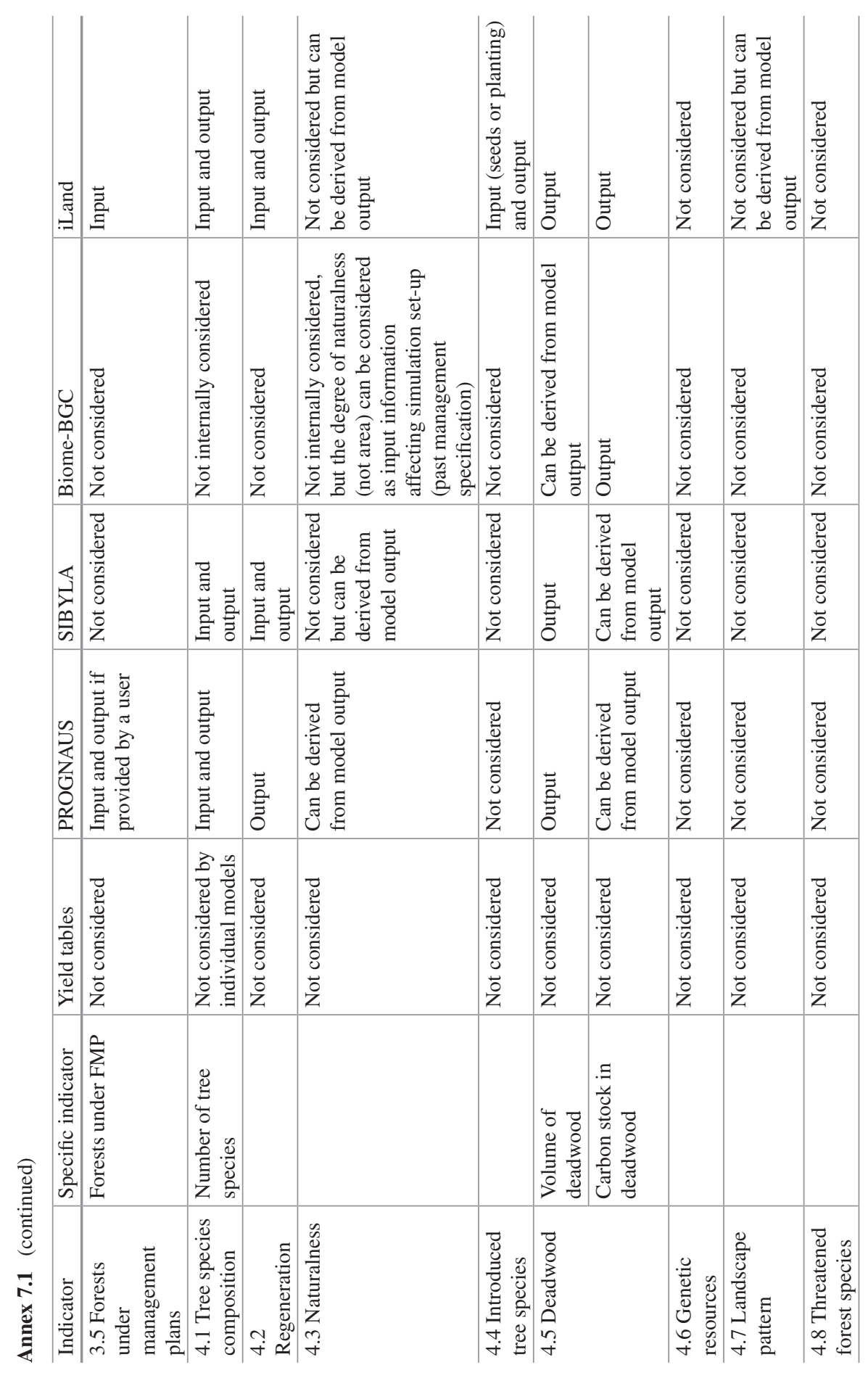




\begin{tabular}{|c|c|c|c|c|c|c|c|c|c|c|}
\hline $\begin{array}{l}\vec{\Xi} \\
\text { 吾 }\end{array}$ & 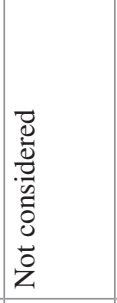 & 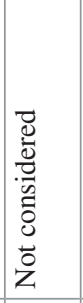 & 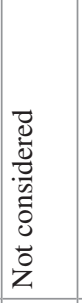 & 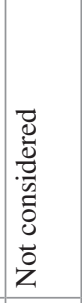 & 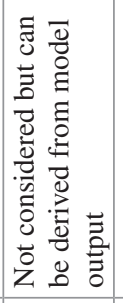 & $\begin{array}{l} \\
\\
\Xi \\
\Xi\end{array}$ & 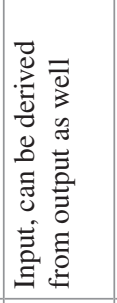 & 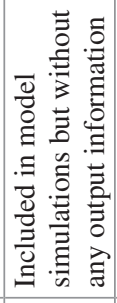 & 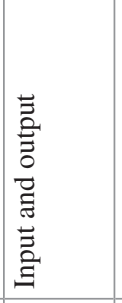 & 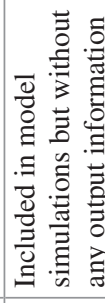 \\
\hline 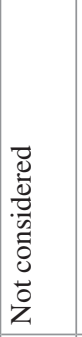 & $\begin{array}{l}\overrightarrow{0} \\
\frac{0}{0} \\
\frac{0}{0} \\
0 \\
0 \\
0 \\
0 \\
z\end{array}$ & 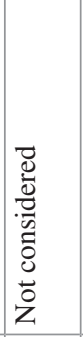 & 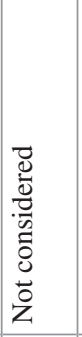 & 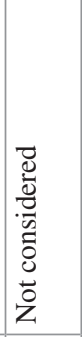 & 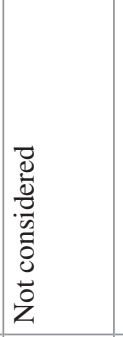 & 芯 & $\begin{array}{l}\overrightarrow{0} \\
\frac{0}{0} \\
0 \overline{0} \\
0 \\
0 \\
0 \\
0 \\
z\end{array}$ & 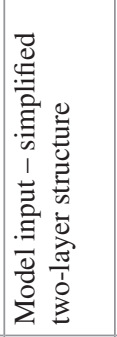 & $\begin{array}{l}\overrightarrow{0} \\
\frac{0}{0} \\
0 \overline{0} \\
0 \\
0 \\
0 \\
0 \\
z\end{array}$ & 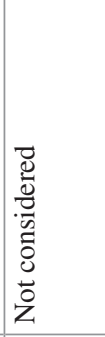 \\
\hline 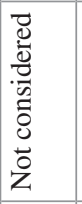 & 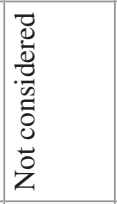 & 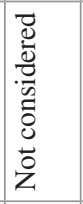 & 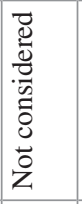 & 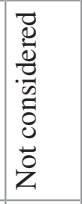 & 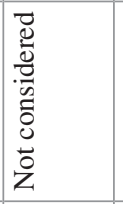 & 意 & 言 & 壳 & 言 & 言 \\
\hline 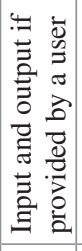 & 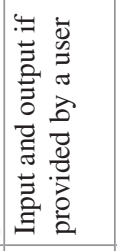 & 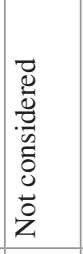 & 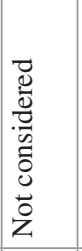 & 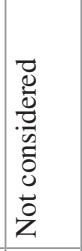 & 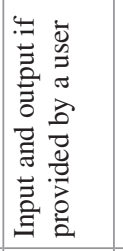 & 音 & 蒿 & 訔 & 言 & 言 \\
\hline 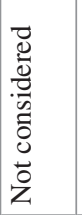 & 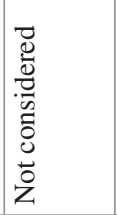 & 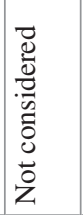 & 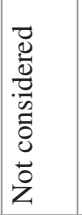 & 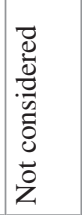 & 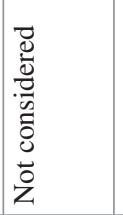 & 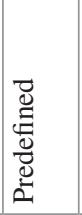 & 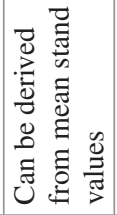 & 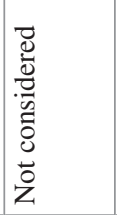 & 言 & $\begin{array}{l}0 \\
0 \\
0 \\
0 \\
0 \\
0 \\
0 \\
0 \\
z \\
z\end{array}$ \\
\hline & & & & & & & & & 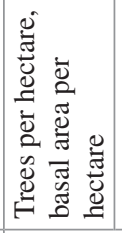 & 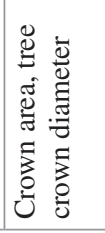 \\
\hline 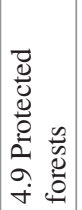 & 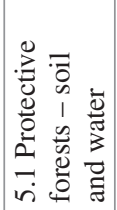 & 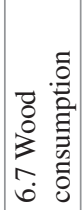 & 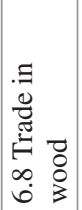 & 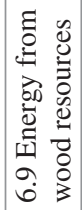 & 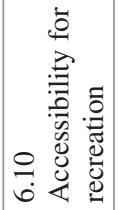 & 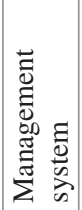 & 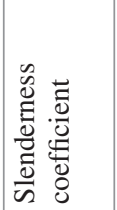 & 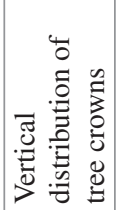 & 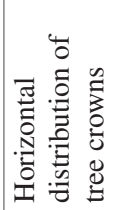 & \\
\hline
\end{tabular}




\section{References}

Alberdi I, Bender S, Riedel T et al (2020) Assessing forest availability for wood supply in Europe. For Policy Econ 111:102032. https://doi.org/10.1016/j.forpol.2019.102032

Albrich K, Rammer W, Seidl R (2020) Climate change causes critical transitions and irreversible alterations of mountain forests. Glob Chang Biol. https://doi.org/10.1111/gcb.15118

Babst F, Poulter B, Trouet V et al (2013) Site- and species-specific responses of forest growth to climate across the European continent. Glob Ecol Biogeogr 22:706-717. https://doi.org/10.1111/ geb. 12023

Babst F, Alexander MR, Szejner P et al (2014a) A tree-ring perspective on the terrestrial carbon cycle. Oecologia 176:307-322. https://doi.org/10.1007/s00442-014-3031-6

Babst F, Bouriaud O, Papale D et al (2014b) Above-ground woody carbon sequestration measured from tree rings is coherent with net ecosystem productivity at five eddy-covariance sites. New Phytol 201:1289-1303. https://doi.org/10.1111/nph.12589

Babst F, Bodesheim P, Charney N et al (2018) When tree rings go global: challenges and opportunities for retro- and prospective insight. Quat Sci Rev 197:1-20. https://doi.org/10.1016/j. quascirev.2018.07.009

Babst F, Bouriaud O, Poulter B et al (2019) Twentieth century redistribution in climatic drivers of global tree growth. Sci Adv 5:eaat4313. https://doi.org/10.1126/sciadv.aat4313

Baldocchi DD (2003) Assessing the eddy covariance technique for evaluating carbon dioxide exchange rates of ecosystems: past, present and future. Glob Chang Biol 9:479-492. https:// doi.org/10.1046/j.1365-2486.2003.00629.x

Battaglia M, Sands PJ (1998) Process-based forest productivity models and their application in forest management. For Ecol Manag 102:13-32. https://doi.org/10.1016/S0378-1127(97)00112-6

Berzaghi F, Wright IJ, Kramer K et al (2020) Towards a new generation of trait-flexible vegetation models. Trends Ecol Evol 35:191-205. https://doi.org/10.1016/j.tree.2019.11.006

Bosela M, Popa I, Gömöry D et al (2016a) Effects of postglacial phylogeny and genetic diversity on the growth variability and climate sensitivity of European silver fir. J Ecol 104:716-724. https://doi.org/10.1111/1365-2745.12561

Bosela M, Redmond J, Kučera M et al (2016b) Stem quality assessment in European National Forest Inventories: an opportunity for harmonised reporting? Ann For Sci 73. https://doi. org/10.1007/s13595-015-0503-8

Bosela M, Štefančík I, Petráš R, Vacek S (2016c) The effects of climate warming on the growth of European beech forests depend critically on thinning strategy and site productivity. Agric For Meteorol 222:21-31. https://doi.org/10.1016/j.agrformet.2016.03.005

Bowditch E, Santopuoli G, Binder F et al (2020) What is climate-smart forestry? A definition from a multinational collaborative process focused on mountain regions of Europe. Ecosyst Serv 43:101113. https://doi.org/10.1016/j.ecoser.2020.101113

Bräutigam K, Vining KJ, Lafon-Placette C et al (2013) Epigenetic regulation of adaptive responses of forest tree species to the environment. Ecol Evol 3:399-415. https://doi.org/10.1002/ ece 3.461

Bravo F, Fabrika M, Ammer C et al (2019) Modelling approaches for mixed forests dynamics prognosis. Research gaps and opportunities. For Syst 28:eR002. https://doi.org/10.5424/ fs/2019281-14342

Bugmann HKM (1996) A simplified Forest model to study species composition along climate gradients. Ecology 77:2055-2074. https://doi.org/10.2307/2265700

Bugmann H, Seidl R, Hartig F et al (2019) Tree mortality submodels drive simulated long-term forest dynamics: assessing 15 models from the stand to global scale. Ecosphere 10:e02616. https://doi.org/10.1002/ecs2.2616

Burkhart HE, Tomé M (2012a) Modeling forest stand development. In: Burkhart HE, Tomé M (eds) Modeling Forest trees and stands. Springer, Dordrecht, pp 233-244

Burkhart HE, Tomé M (2012b) Evaluating site quality. In: Burkhart HE, Tomé M (eds) Modeling forest trees and stands. Springer, Dordrecht, pp 131-173 
Burkhart HE, Tomé M (2012c) Growth functions. In: Burkhart HE, Tomé M (eds) Modeling forest trees and stands. Springer, Dordrecht, pp 111-130

Charney ND, Babst F, Poulter B et al (2016) Observed forest sensitivity to climate implies large changes in 21st century North American forest growth. Ecol Lett 19:1119-1128. https://doi. org/10.1111/ele.12650

Chen PY, Welsh C, Hamann A (2010) Geographic variation in growth response of Douglas-fir to interannual climate variability and projected climate change. Glob Chang Biol 16:3374-3385. https://doi.org/10.1111/j.1365-2486.2010.02166.x

Cherubini P, Dobbertin M, Innes JL (1998) Potential sampling bias in long-term forest growth trends reconstructed from tree rings: a case study from the Italian Alps. For Ecol Manag 109:103-118. https://doi.org/10.1016/S0378-1127(98)00242-4

Christmann (1949) Ertragstafel für Kiefern-Fichten-Mischbestand. In: Ertragstafeln der wichtigsten Holzarten bei verschiedener Durchforstung sowie einiger Mischbestandsformen. Schaper, Hannover, p 100

Cook E, Kairiukstis L (1990) Methods of dendrochronology: applications in the environmental sciences. Springer, Berlin

Cornes R, van der Schrier G, van der Besselaar EJM, Jones PD (2018) An ensemble version of the E-OBS temperature and precipitation datasets. J Geophys Res Atmos 123:9391-9409. https:// doi.org/10.1029/2017JD028200

D' Amato AW, Bradford JB, Fraver S, Palik BJ (2011) Forest management for mitigation and adaptation to climate change: insights from long-term silviculture experiments. For Ecol Manag 262:803-816. https://doi.org/10.1016/j.foreco.2011.05.014

Deckmyn G, Verbeeck H, Op de Beeck M et al (2008) ANAFORE: a stand-scale process-based forest model that includes wood tissue development and labile carbon storage in trees. Ecol Model 215:345-368. https://doi.org/10.1016/j.ecolmodel.2008.04.007

Dorado-Liñán I, Piovesan G, Martínez-Sancho E et al (2019) Geographical adaptation prevails over species-specific determinism in trees' vulnerability to climate change at Mediterranean rear-edge forests. Glob Chang Biol 25:1296-1314. https://doi.org/10.1111/gcb.14544

Dormann CF, Calabrese JM, Guillera-Arroita G et al (2018) Model averaging in ecology: a review of Bayesian, information-theoretic, and tactical approaches for predictive inference. Ecol Monogr 88:485-504. https://doi.org/10.1002/ecm.1309

Eriksson G, Namkoong G, Roberds JH (1993) Dynamic gene conservation for uncertain futures. For Ecol Manag 62:15-37. https://doi.org/10.1016/0378-1127(93)90039-P

Fabrika M (2005) Simulátor biodynamiky lesa SIBYLA, koncepcia, konštrukcia a programové riešenie. Technical University in Zvolen

Fabrika M, Pretzsch H (2013) Forest ecosystem analysis and modelling, 1st edn. Technical University in Zvolen, Zvolen

Fabrika M, Pretzsch H, Bravo F (2018) Models for mixed forests BT - dynamics, silviculture and management of mixed forests. In: Bravo-Oviedo A, Pretzsch H, del Río M (eds) . Springer, Cham, pp 343-380

Fabrika M, Valent P, Merganicova K (2019) Forest modelling and visualisation - state of the art and perspectives. Cent Eur For J 66:147-165. https://doi.org/10.2478/forj-2019-0018

Fahey RT, Alveshere BC, Burton JI et al (2018) Shifting conceptions of complexity in forest management and silviculture. For Ecol Manag 421:59-71. https://doi.org/10.1016/j. foreco.2018.01.011

Fischer C, Gasparini P, Nylander M et al (2016) Joining criteria for harmonizing European Forest available for wood supply estimates. Case studies from National Forest Inventories. Forests 7:104. https://doi.org/10.3390/f7050104

Fontes L, Bontemps J-D, Bugmann H et al (2010) Models for supporting forest management in a changing environment. For Syst 3:8. https://doi.org/10.5424/fs/201019s-9315

FOREST EUROPE (2015) State of Europe's Forests:2015

Forrester DI, Tang X (2016) Analysing the spatial and temporal dynamics of species interactions in mixed-species forests and the effects of stand density using the 3-PG model. Ecol Model 319:233-254. https://doi.org/10.1016/j.ecolmodel.2015.07.010 
Frampton WJ, Dash J, Watmough G, Milton EJ (2013) Evaluating the capabilities of Sentinel-2 for quantitative estimation of biophysical variables in vegetation. ISPRS J Photogramm Remote Sens 82:83-92. https://doi.org/10.1016/j.isprsjprs.2013.04.007

Frank A, Sperisen C, Howe GT et al (2017) Distinct genecological patterns in seedlings of Norway spruce and silver fir from a mountainous landscape. Ecology 98:211-227. https://doi. org/10.1002/ecy. 1632

Fritts HC (2001) Tree rings and climate. The Blackburn Press, New York/San Francisco

Fritts HC, Swetnam TW (1989) Dendroecology: a tool for evaluating variations in past and present forest environments. Academic

Fritts HC, Vaganov EA, Sviderskaya IV, Shashkin AV (1991) Climatic variation and tree-ring structure in conifers: empirical and mechanistic models of tree-ring width, number of cells, cell size, cell-wall thickness and wood density. Clim Res 1:97-116

Girardin MP, Raulier F, Bernier PY, Tardif JC (2008) Response of tree growth to a changing climate in boreal Central Canada: a comparison of empirical, process-based, and hybrid modelling approaches. Ecol Model 213:209-228. https://doi.org/10.1016/j.ecolmodel.2007.12.010

Gitelson AA, Gamon JA (2015) The need for a common basis for defining light-use efficiency: implications for productivity estimation. Remote Sens Environ 156:196-201. https://doi. org/10.1016/j.rse.2014.09.017

Grīnvalds A (2014) The accuracy of standwise forest inventory in mature stands. Proc Latv Univ Agric 32:1-8. https://doi.org/10.2478/plua-2014-0007

Gschwantner T, Lanz A, Vidal C et al (2016) Comparison of methods used in European National Forest Inventories for the estimation of volume increment: towards harmonisation. Ann For Sci:73. https://doi.org/10.1007/s13595-016-0554-5

Guiot J, Boucher E, Gea-Izquierdo G (2014) Process models and model-data fusion in dendroecology. Front Ecol Evol 2:52

Gutsch M, Lasch-Born P, Kollas C et al (2018) Balancing trade-offs between ecosystem services in Germany's forests under climate change. Environ Res Lett 13:45012. https://doi. org/10.1088/1748-9326/aab4e5

Haines-Young R, Potschin MB (2018) Common International Classification of Ecosystem Services (CICES) V5.1

Halaj J, Petráš R (1998) Rastové tabul'ky hlavných drevín [Growth tables of the main tree species]. SAP - Slovak Academic Press, Bratislava

Harris I, Jones PD, Osborn TJ, Lister DH (2014) Updated high-resolution grids of monthly climatic observations - the CRU TS3.10 Dataset. Int J Climatol 34:623-642. https://doi.org/10.1002/ joc. 3711

Hart SJ, Veblen TT, Eisenhart KS et al (2014) Drought induces spruce beetle (Dendroctonus rufipennis) outbreaks across northwestern Colorado. Ecology 95:930-939

Hart SJ, Veblen TT, Schneider D, Molotch NP (2017) Summer and winter drought drive the initiation and spread of spruce beetle outbreak. Ecology 98:2698-2707. https://doi.org/10.1002/ ecy. 1963

Hasenauer H (1994) Ein Einzelbaumsimulator für ungleichaltrige Fichten-Kieferen- und BuchenFichtenmischbestände. Forstliche Schriftenreihe Universität für Bodenkultur, Wien, Band 8

Hauhs M, Kastner-Maresch A, Rost-Siebert K (1995) A model relating forest growth to ecosystem-scale budgets of energy and nutrients. Ecol Model 83:229-243. https://doi. org/10.1016/0304-3800(95)00101-Z

He HS (2008) Forest landscape models: definitions, characterization, and classification. For Ecol Manag 254:484-498. https://doi.org/10.1016/j.foreco.2007.08.022

Henne PD, Elkin C, Colombaroli D et al (2013) Impacts of changing climate and land use on vegetation dynamics in a Mediterranean ecosystem: insights from paleoecology and dynamic modeling. Landsc Ecol 28:819-833. https://doi.org/10.1007/s10980-012-9782-8

Hewitt G (2000) The genetic legacy of the quaternary ice ages. Nature 405:907-913. https://doi. org/10.1038/35016000

Hewitt GM (2004) Genetic consequences of climatic oscillations in the quaternary. Philos Trans R Soc Lond Ser B Biol Sci 359:183-195. https://doi.org/10.1098/rstb.2003.1388 
Hlásny T, Barcza Z, Fabrika M et al (2011) Climate change impacts on growth and carbon balance of forests in Central Europe. Clim Res 47:219-236. https://doi.org/10.3354/cr01024

Hlásny T, Barcza Z, Barka I et al (2014) Future carbon cycle in mountain spruce forests of Central Europe: modelling framework and ecological inferences. For Ecol Manag 328:55-68. https:// doi.org/10.1016/j.foreco.2014.04.038

Horemans JA, Bosela M, Dobor L et al (2016) Variance decomposition of predictions of stem biomass increment for European beech: contribution of selected sources of uncertainty. For Ecol Manag:361. https://doi.org/10.1016/j.foreco.2015.10.048

Howe GT, Aitken SN, Neale DB et al (2003) From genotype to phenotype: unraveling the complexities of cold adaptation in forest trees. Can J Bot 81:1247-1266

Huang J, Gómez-Dans JL, Huang H et al (2019) Assimilation of remote sensing into crop growth models: current status and perspectives. Agric For Meteorol 276-277:107609. https://doi. org/10.1016/j.agrformet.2019.06.008

Hubau W, Lewis SL, Phillips OL et al (2020) Asynchronous carbon sink saturation in African and Amazonian tropical forests. Nature 579:80-87. https://doi.org/10.1038/s41586-020-2035-0

Huber N, Bugmann H, Lafond V (2018) Global sensitivity analysis of a dynamic vegetation model: model sensitivity depends on successional time, climate and competitive interactions. Ecol Model 368:377-390. https://doi.org/10.1016/j.ecolmodel.2017.12.013

IPCC (2014) Climate change 2014: synthesis report. Contribution of Working Groups I, II and III to the Fifth Assessment Report of the Intergovernmental Panel on Climate Change [Core Writing Team, Pachauri RK, Meyer LA (eds)]

Jacob D, Petersen J, Eggert B et al (2014) EURO-CORDEX: new high-resolution climate change projections for European impact research. Reg Environ Chang 14:563-578. https://doi. org/10.1007/s10113-013-0499-2

Jandl R, Ledermann T, Kindermann G et al (2018) Strategies for climate-smart forest management in Austria. Forest 9

Jin H, Eklundh L (2014) A physically based vegetation index for improved monitoring of plant phenology. Remote Sens Environ 152:512-525. https://doi.org/10.1016/j.rse.2014.07.010

Jönsson AM, Appelberg G, Harding S, Bärring L (2009) Spatio-temporal impact of climate change on the activity and voltinism of the spruce bark beetle, Ips typographus. Glob Chang Biol 15:486-499. https://doi.org/10.1111/j.1365-2486.2008.01742.x

Jucker T, Bouriaud O, Avacaritei D, Coomes DA (2014) Stabilizing effects of diversity on aboveground wood production in forest ecosystems: linking patterns and processes. Ecol Lett 17:1560-1569. https://doi.org/10.1111/ele.12382

Kahn M (1994) Modellierung der Höhenentwicklung ausgewählter Baumarten in Abhängigkeit vom Standort. Forstliche Forschungsber. München, vol 141

Kapos V, Rhind J, Edwards M et al (2000) Developing a map of the world's mountain forests. In: Price MF, Butt N (eds) Forests in sustainable mountain development: a state-of knowledge report for 2000. CAB International, Wallingford, pp 4-19

Keenan TF, Hollinger DY, Bohrer G et al (2013) Increase in forest water-use efficiency as atmospheric carbon dioxide concentrations rise. Nature 499:324-327. https://doi.org/10.1038/ nature 12291

Klesse S, DeRose RJ, Guiterman CH et al (2018) Sampling bias overestimates climate change impacts on forest growth in the southwestern United States. Nat Commun 9:1-9. https://doi. org/10.1038/s41467-018-07800-y

Köhler P, Huth A (1998) The effects of tree species grouping in tropical rainforest modelling: simulations with the individual-based model Formind. Ecol Model 109:301-321. https://doi. org/10.1016/S0304-3800(98)00066-0

Koivuniemi J, Korhonen K (2006) Inventory by compartments. In: Kangas A, Maltamo M (eds) Forest inventory: methodology and applications. Springer Dordrecht, pp. 271-278

Kramer K, Leinonen I, Bartelink HH et al (2002) Evaluation of six process-based forest growth models using eddy-covariance measurements of $\mathrm{CO} 2$ and $\mathrm{H} 2 \mathrm{O}$ fluxes at six forest sites in Europe. Glob Chang Biol 8:213-230. https://doi.org/10.1046/j.1365-2486.2002.00471.x 
Kramer K, Degen B, Buschbom J et al (2010) Modelling exploration of the future of European beech (Fagus sylvatica L.) under climate change-range, abundance, genetic diversity and adaptive response. For Ecol Manag 259:2213-2222. https://doi.org/10.1016/j.foreco.2009.12.023

Kramer K, van der Werf B, Schelhaas M-J (2015) Bring in the genes: genetic-ecophysiological modeling of the adaptive response of trees to environmental change. With application to the annual cycle. Front Plant Sci 5:1-10. https://doi.org/10.3389/fpls.2014.00742

Kramer K, Ducousso A, Gömöry D et al (2017) Chilling and forcing requirements for foliage bud burst of European beech (Fagus sylvatica L.) differ between provenances and are phenotypically plastic. Agric For Meteorol 234-235:172-181. https://doi.org/10.1016/j. agrformet.2016.12.002

Lafond V, Lagarrigues G, Cordonnier T, Courbaud B (2014) Uneven-aged management options to promote forest resilience for climate change adaptation: effects of group selection and harvesting intensity. Ann For Sci 71:173-186. https://doi.org/10.1007/s13595-013-0291-y

Landsberg JJ, Waring RH (1997) A generalised model of forest productivity using simplified concepts of radiation-use efficiency, carbon balance and partitioning. For Ecol Manag 95:209-228. https://doi.org/10.1016/S0378-1127(97)00026-1

Lasslop G, Reichstein M, Kattge J, Papale D (2008) Influences of observation errors in eddy flux data on inverse model parameter estimation. Biogeosciences 5:1311-1324. https://doi. org/10.5194/bg-5-1311-2008

Liang L, Di L, Zhang L et al (2015) Estimation of crop LAI using hyperspectral vegetation indices and a hybrid inversion method. Remote Sens Environ 165:123-134. https://doi.org/10.1016/j. rse.2015.04.032

Liepelt S, Cheddadi R, de Beaulieu JL et al (2009) Postglacial range expansion and its genetic imprints in Abies alba (Mill.) - a synthesis from palaeobotanic and genetic data. Rev Palaeobot Palynol 153:139-149. https://doi.org/10.1016/j.revpalbo.2008.07.007

Lischke H, Zimmermann NE, Bolliger J et al (2006) TreeMig: a forest-landscape model for simulating spatio-temporal patterns from stand to landscape scale. Ecol Model 199:409-420. https://doi.org/10.1016/j.ecolmodel.2005.11.046

Liu Q, Fu YH, Liu Y et al (2018) Simulating the onset of spring vegetation growth across the Northern Hemisphere. Glob Chang Biol 24:1342-1356. https://doi.org/10.1111/gcb.13954

Mäkelä A, Landsberg J, Ek AR et al (2000) Process-based models for forest ecosystem management: current state of the art and challenges for practical implementation. Tree Physiol 20:289-298. https://doi.org/10.1093/treephys/20.5-6.289

Mäkelä A, Grace DG et al (2010) Simulating wood quality in forest management models. For Syst 19:48-68. https://doi.org/10.5424/fs/201019S-9314

Mäkelä A, del Río M, Hynynen J et al (2012) Using stand-scale forest models for estimating indicators of sustainable forest management. For Ecol Manag 285:164-178. https://doi. org/10.1016/j.foreco.2012.07.041

Mausolf K, Wilm P, Härdtle W et al (2018) Higher drought sensitivity of radial growth of European beech in managed than in unmanaged forests. Sci Total Environ 642:1201-1208. https://doi. org/10.1016/j.scitotenv.2018.06.065

McCullagh A, Black K, Nieuwenhuis M (2017) Evaluation of tree and stand-level growth models using national forest inventory data. Eur J For Res 136:251-258. https://doi.org/10.1007/ s10342-017-1025-8

Meddens AJH, Hicke JA, Vierling LA, Hudak AT (2013) Evaluating methods to detect bark beetlecaused tree mortality using single-date and multi-date Landsat imagery. Remote Sens Environ 132:49-58. https://doi.org/10.1016/j.rse.2013.01.002

Meier ES, Lischke H, Schmatz DR, Zimmermann NE (2012) Climate, competition and connectivity affect future migration and ranges of European trees. Glob Ecol Biogeogr 21:164-178. https://doi.org/10.1111/j.1466-8238.2011.00669.x

Merganič J, Merganičová K, Výbošt’ok J et al (2020) Searching for Pareto fronts for forest stand wind stability by incorporating timber and biodiversity values. Forest 11

Merganičová K, Pietsch SA, Hasenauer H (2005) Testing mechanistic modeling to assess impacts of biomass removal. For Ecol Manag 207:37-57. https://doi.org/10.1016/j.foreco.2004.10.017 
Merganičová K, Merganič J, Lehtonen A et al (2019) Forest carbon allocation modelling under climate change. Tree Physiol 39:1937-1960. https://doi.org/10.1093/treephys/tpz105

Meyer G, Black TA, Jassal RS et al (2018) Simulation of net ecosystem productivity of a lodgepole pine forest after mountain pine beetle attack using a modified version of 3-PG. For Ecol Manag 412:41-52. https://doi.org/10.1016/j.foreco.2018.01.034

Michel A, Prescher A-K, Schwärzel K (2019) Forest condition in Europe: 2019 technical report of ICP forests. Report under the UNECE Convention on Long-range Transboundary Air Pollution (Air Convention). BFW-Dokumentation 27/2019, Vienna, Austria

Mina M, Bugmann H, Klopcic M, Cailleret M (2017) Accurate modeling of harvesting is key for projecting future forest dynamics: a case study in the Slovenian mountains. Reg Environ Chang 17:49-64. https://doi.org/10.1007/s10113-015-0902-2

Minunno F, Peltoniemi M, Härkönen S et al (2019) Bayesian calibration of a carbon balance model PREBAS using data from permanent growth experiments and national forest inventory. For Ecol Manag 440:208-257. https://doi.org/10.1016/j.foreco.2019.02.041

Mo X, Chen JM, Ju W, Black TA (2008) Optimization of ecosystem model parameters through assimilating eddy covariance flux data with an ensemble Kalman filter. Ecol Model 217:157-173. https://doi.org/10.1016/j.ecolmodel.2008.06.021

Monserud RA, Sterba H (1996) A basal area increment model for individual trees growing in even- and uneven-aged forest stands in Austria. For Ecol Manag 80:57-80. https://doi. org/10.1016/0378-1127(95)03638-5

Moreno A, Hasenauer H (2016) Spatial downscaling of European climate data. Int J Climatol 36:1444-1458. https://doi.org/10.1002/joc.4436

Moss RH, Edmonds JA, Hibbard KA et al (2010) The next generation of scenarios for climate change research and assessment. Nature 463:747-756. https://doi.org/10.1038/nature08823

Nabuurs G-J, Lindner M, Verkerk PJ et al (2013) First signs of carbon sink saturation in European forest biomass. Nat Clim Chang 3:792-796. https://doi.org/10.1038/nclimate1853

Nabuurs GJ, Arets EJMM, Schelhaas MJ (2018) Understanding the implications of the EU-LULUCF regulation for the wood supply from EU forests to the EU 07 Agricultural and Veterinary Sciences 0705 Forestry Sciences Georgii Alexandrov. Carbon Balance Manag 13:18. https://doi.org/10.1186/s13021-018-0107-3

Nagel J (1996) Anwendungsprogramm zur Bestandesbewertung und zur Prognose der Bestandesentwicklung. Forst und Holz 3:76-78

Nagel J (1999) Konzeptionelle Überlegungen zum schrittweisen Aufbau eines waldwachstumskundlichen Simulationssystems für Nordwestdeutschland. Schriften aus der Forstlichen Fakultät der Universität Göttingen und der Niedersächsischen Forstlichen Versuchsanstalt. J. D. Sauerländer's verlag, Frankfurt am Main

Nakicenovic N, Davidson O, Davis G et al (2000) Special report on emissions scenarios: a special report of the Working Group III of the Intergovernmental Panel on Climate Change

Namkoong G (1998) Forest genetics and conservation in Europe. In: Turok J, Palmberg-Lerche C, Skroppa T, Ouedraogo AS (eds) Conservation of forest genetic resources in Europe. Proceedings of the European Forest Genetic Resources Workshop, 21 November 1995. International Plant Genetic Resources Institute, Sopron, Hingary, pp. 3-10

Neale DB, Wheeler N (2019) The conifers: genomes, variation and evolution. Springer International Publishing

Nehrbass-Ahles C, Babst F, Klesse S et al (2014) The influence of sampling design on tree-ringbased quantification of forest growth. Glob Chang Biol 20:2867-2885. https://doi.org/10.1111/ gcb. 12599

Neumann M, Moreno A, Thurnher C et al (2016) Creating a regional MODIS satellite-driven net primary production dataset for European forests. Remote Sens 8

Noormets A, Epron D, Domec JC et al (2015) Effects of forest management on productivity and carbon sequestration: a review and hypothesis. For Ecol Manag 355:124-140. https://doi. org/10.1016/j.foreco.2015.05.019

Nyström M, Lindgren N, Wallerman J et al (2015) Data assimilation in forest inventory: first empirical results. Forests 6:4540-4557 
O'Hara KL (2006) Multiaged forest stands for protection forests: concepts and applications. For Snow Landsc Res 80:45-55

O'Hara KL, Ramage BS (2013) Silviculture in an uncertain world: utilizing multi-aged management systems to integrate disturbance $\dagger$. For An Int J For Res 86:401-410. https://doi. org/10.1093/forestry/cpt012

Pan Y, Birdsey RA, Fang J et al (2011) A large and persistent carbon sink in the world's forests. Science 333:988-993. https://doi.org/10.1126/science.1201609

Pappas C, Bélanger N, Bergeron Y, et al (2021) Smartforests Canada - A network of monitoring plots for forest management under environmental change. In: Managing Forest Ecosystems, Vol. 40, Tognetti R, Smith M, Panzacchi P (Eds): Climate-Smart Forestry in Mountain Regions. Springer Nature, Switzerland, AG

Peters RL, Groenendijk P, Vlam M, Zuidema PA (2015) Detecting long-term growth trends using tree rings: a critical evaluation of methods. Glob Chang Biol 21:2040-2054. https://doi. org/10.1111/gcb.12826

Petit RJ, Aguinagalde I, de Beaulieu J-L et al (2003) Glacial refugia: hotspots but not melting pots of genetic diversity. Science (80-) 300:1563-1565. https://doi.org/10.1126/science.1083264

Picard N, Henry M, Mortier F et al (2012) Using Bayesian model averaging to predict tree aboveground biomass in tropical moist forests. For Sci 58:15-23. https://doi.org/10.5849/forsci.10-083

Porté A, Bartelink HH (2002) Modelling mixed forest growth: a review of models for forest management. Ecol Model 150:141-188. https://doi.org/10.1016/S0304-3800(01)00476-8

Pretzsch H (2009) Forest Dynamics, Growth and Yield. From Measurement to Model. SpringerVerlag Berlin Heidelberg, 664 pp. https://doi.org/10.1007/978-3-540-88307-4

Pretzsch H (2020) The course of tree growth. Theory and reality. For Ecol Manag 478:118508. https://doi.org/10.1016/j.foreco.2020.118508

Pretzsch H, Schütze G (2009) Transgressive overyielding in mixed compared with pure stands of Norway spruce and European beech in Central Europe: evidence on stand level and explanation on individual tree level. Eur J For Res 128:183-204. https://doi.org/10.1007/ s10342-008-0215-9

Pretzsch H, Schütze G (2015) Effect of tree species mixing on the size structure, density, and yield of forest stands. Eur J For Res. https://doi.org/10.1007/s10342-015-0913-z

Pretzsch H, Biber P, Ďurský J (2002) The single tree-based stand simulator SILVA: construction, application and evaluation. For Ecol Manag 162:3-21. https://doi.org/10.1016/ S0378-1127(02)00047-6

Pretzsch H, Block J, Dieler J et al (2010) Comparison between the productivity of pure and mixed stands of Norway spruce and European beech along an ecological gradient. Ann For Sci 67:712-712. https://doi.org/10.1051/forest/2010037

Pretzsch H, Biber P, Schütze G et al (2014) Forest stand growth dynamics in Central Europe has accelerated since 1870. Nat Commun 5:4967. https://doi.org/10.1038/ncomms5967

Pretzsch H, Forrester DI, Rötzer T (2015) Representation of species mixing in forest growth models: a review and perspective. Ecol Model 313:276-292. https://doi.org/10.1016/j. ecolmodel.2015.06.044

Pretzsch H, Hilmers T, Uhl E, et al (2021) Efficacy of trans-geographic observational network design for revelation of growth pattern in mountain forests across Europe. In: Managing Forest Ecosystems, Vol. 40, Tognetti R, Smith M, Panzacchi P (Eds): Climate-Smart Forestry in Mountain Regions. Springer Nature, Switzerland, AG

Puettmann KJ (2011) Silvicultural challenges and options in the context of global change: "simple" fixes and opportunities for new management approaches. J For 109:321-331. https://doi. org/10.1093/jof/109.6.321

Rasche L, Fahse L, Zingg A, Bugmann H (2011) Getting a virtual forester fit for the challenge of climatic change. J Appl Ecol 48:1174-1186. https://doi.org/10.1111/j.1365-2664.2011.02014.x

Rauscher HM, Isebrands JG, Host GE et al (1990) ECOPHYS: an ecophysiological growth process model for juvenile poplar. Tree Physiol 7:255-281. https://doi.org/10.1093/ treephys/7.1-2-3-4.255 
Rocha A, Goulden M, Dunn A, Wofsy S (2006) On linking interannual tree ring variability with observations of whole-forest CO2 flux. Glob Chang Biol 12:1378-1389. https://doi. org/10.1111/j.1365-2486.2006.01179.x

Rötzer T, Seifert T, Pretzsch H (2009) Modelling above and below ground carbon dynamics in a mixed beech and spruce stand influenced by climate. Eur J For Res 128:171-182. https://doi. org/10.1007/s10342-008-0213-y

Rötzer T, Leuchner M, Nunn AJ (2010) Simulating stand climate, phenology, and photosynthesis of a forest stand with a process-based growth model. Int J Biometeorol 54:449-464. https://doi. org/10.1007/s00484-009-0298-0

Rüetschi M, Small D, Waser LT (2019) Rapid detection of windthrows using Sentinel-1 C-band SAR data. Remote Sens 11

Rummukainen M (2010) State-of-the-art with regional. Clim Chang 1:82-96. https://doi. org/10.1002/wcc.008

Sánchez-Salguero R, Camarero JJ, Gutiérrez E et al (2017) Assessing forest vulnerability to climate warming using a process-based model of tree growth: bad prospects for rear-edges. Glob Chang Biol:2705-2719. https://doi.org/10.1111/gcb.13541

Schelhaas MJ, Eggers J, Lindner M et al (2007) Model documentation for the European Forest Information Scenario model (EFISCEN 3.1.3). Alterra, 268, Centrum Ecosystemen,

Scherrer D, Vitasse Y, Guisan A et al (2020) Competition and demography rather than dispersal limitation slow down upward shifts of trees' upper elevation limits in the Alps. J Ecol. https:// doi.org/10.1111/1365-2745.13451

Schuler LJ, Bugmann H, Petter G, Snell RS (2019) How multiple and interacting disturbances shape tree diversity in European mountain landscapes. Landsc Ecol 34:1279-1294. https://doi. org/10.1007/s10980-019-00838-3

Schumacher S, Bugmann H, Mladenoff DJ (2004) Improving the formulation of tree growth and succession in a spatially explicit landscape model. Ecol Model 180:175-194. https://doi. org/10.1016/j.ecolmodel.2003.12.055

Seidl R, Schelhaas MJ, Lexer MJ (2011) Unraveling the drivers of intensifying forest disturbance regimes in Europe. Glob Chang Biol 17:2842-2852. https://doi. org/10.1111/j.1365-2486.2011.02452.x

Seidl R, Rammer W, Scheller RM, Spies TA (2012) An individual-based process model to simulate landscape-scale forest ecosystem dynamics. Ecol Model 231:87-100. https://doi.org/10.1016/j. ecolmodel.2012.02.015

Seidl R, Schelhaas M-J, Rammer W, Verkerk PJ (2014) Increasing forest disturbances in Europe and their impact on carbon storage. Nat Clim Chang 4:806-810. https://doi.org/10.1038/ nclimate 2318

Seidl R, Albrich K, Erb K et al (2019) What drives the future supply of regulating ecosystem services in a mountain forest landscape? For Ecol Manag 445:37-47. https://doi.org/10.1016/j. foreco.2019.03.047

Seintsch B, Döring P, Dunger K et al (2017) Das WEHAM-Szenarien Verbundforschungsprojekt. AFZ/Der Wald 72:10-13

Shifley SR, He HS, Lischke H et al (2017) The past and future of modeling forest dynamics: from growth and yield curves to forest landscape models. Landsc Ecol 32:1307-1325. https://doi. org/10.1007/s10980-017-0540-9

Skovsgaard JP, Vanclay JK (2008) Forest site productivity: a review of the evolution of dendrometric concepts for even-aged stands. Forestry 81:13-31. https://doi.org/10.1093/forestry/cpm041

Socha J, Tymińska-Czabańska L (2019) A method for the development of dynamic site index models using height-age data from temporal sample plots. Forest 10

Sodtke R, Schmidt M, Fabrika M et al (2004) Anwendung und Einsatz von Einzelbaummodellen als Komponenten von entscheidungsunterstützenden Systemen für die strategische Forstbetriebsplannung. Forstarchiv 75:51-64

Sperry JS, Venturas MD, Todd $\mathrm{HN}$ et al (2019) The impact of rising CO2 and acclimation on the response of US forests to global warming. Proc Natl Acad Sci 116:25734-25744. https://doi. org/10.1073/pnas.1913072116 
Spiecker H (2003) Silvicultural management in maintaining biodiversity and resistance of forests in Europe-temperate zone. J Environ Manag 67:55-65. https://doi.org/10.1016/ S0301-4797(02)00188-3

Stadelmann G, Temperli C, Rohner B et al (2019) Presenting MASSIMO: a management scenario simulation model to project growth, harvests and carbon dynamics of Swiss forests. Forest 10

Sterba H (1995) PROGNAUS - ein absandsunabhängiger Wachstumssimulator für ungleichaltrige Mischbestände. In: DVFF - Sektion Ertragskunde. Joachimstahl, pp 173-183

Stute M, Clement A, Lohmann G (2001) Global climate models: past, present, and future. Proc Natl Acad Sci U S A 98:10529-10530. https://doi.org/10.1073/pnas.191366098

Svoboda M, Janda P, Bače R et al (2014) Landscape-level variability in historical disturbance in primary Picea abies mountain forests of the Eastern Carpathians, Romania. J Veg Sci 25:386-401. https://doi.org/10.1111/jvs.12109

Temperli C, Bugmann H, Elkin C (2012) Adaptive management for competing forest goods and services under climate change. Ecol Appl 22:2065-2077. https://doi.org/10.1890/12-0210.1

Temperli C, Veblen TT, Hart SJ et al (2015) Interactions among spruce beetle disturbance, climate change and forest dynamics captured by a forest landscape model. Ecosphere 6:art231. https:// doi.org/10.1890/ES15-00394.1

Temperli C, Blattert C, Stadelmann G et al (2020) Trade-offs between ecosystem service provision and the predisposition to disturbances: a NFI-based scenario analysis. For Ecosyst 7:27. https:// doi.org/10.1186/s40663-020-00236-1

Temperli C, Santopuoli G, Bottero A, et al (2021) National Forest Inventory data to evaluate ClimateSmart Forestry. In: Managing Forest Ecosystems, Vol. 40, Tognetti R, Smith M, Panzacchi P (Eds): Climate-Smart Forestry in Mountain Regions. Springer Nature, Switzerland, AG

Thom D, Rammer W, Seidl R (2017) The impact of future forest dynamics on climate: interactive effects of changing vegetation and disturbance regimes. Ecol Monogr 87:665-684. https://doi. org/10.1002/ecm.1272

Thornton PE, Running SW, Hunt ER (2005) Biome-BGC: terrestrial ecosystem process model, Version 4.1.1

Thrippleton T, Lüscher F, Bugmann H (2020) Climate change impacts across a large forest enterprise in the Northern Pre-Alps: dynamic forest modelling as a tool for decision support. Eur J For Res 139:483-498. https://doi.org/10.1007/s10342-020-01263-x

Tognetti R, Valentini R, Belelli Marchesini L, Gianelle D, Panzacchi P, Marshall JD (2021) Continuous monitoring of tree responses to climate change for smart forestry - a cybernetic web of trees. In: Managing Forest Ecosystems, Vol. 40, Tognetti R, Smith M, Panzacchi P (Eds): Climate-Smart Forestry in Mountain Regions. Springer Nature, Switzerland, AG

Toïgo M, Vallet P, Perot T et al (2015) Overyielding in mixed forests decreases with site productivity. J Ecol 103:502-512. https://doi.org/10.1111/1365-2745.12353

Tolwinski-Ward SE, Evans MN, Hughes MK, Anchukaitis KJ (2011) An efficient forward model of the climate controls on interannual variation in tree-ring width. Clim Dyn 36:2419-2439. https://doi.org/10.1007/s00382-010-0945-5

Tomppo E, Gschwantner T, Lawrence M, McRoberts RE (2010) National forest inventories - pathways for common reporting. Springer

Torresan C, Luyssaert S, Filippa G, Imangholiloo M, Gaulton R (2021) Remote sensing technologies for assessing climate-smart criteria in mountain forests. In: Managing Forest Ecosystems, Vol. 40, Tognetti R, Smith M, Panzacchi P (Eds): Climate-Smart Forestry in Mountain Regions. Springer Nature, Switzerland, AG

Trotsiuk V, Hartig F, Cailleret M et al (2020) Assessing the response of forest productivity to climate extremes in Switzerland using model-data fusion. Glob Chang Biol 26:2463-2476. https://doi.org/10.1111/gcb.15011

Vaganov EA, Hughes MK, Shashkin AV (2006) Growth dynamics of conifer tree rings: images of past and future environments. Springer, Berlin/Heidelberg

van der Plas F, Manning P, Allan E et al (2016) Jack-of-all-trades effects drive biodiversityecosystem multifunctionality relationships in European forests. Nat Commun 7:11109. https:// doi.org/10.1038/ncomms11109 
van Oijen M, Reyer C, Bohn FJ et al (2013) Bayesian calibration, comparison and averaging of six forest models, using data from Scots pine stands across Europe. For Ecol Manag 289:255-268. https://doi.org/10.1016/j.foreco.2012.09.043

Vanclay JK, Skovsgaard JP (1997) Evaluating forest growth models. Ecol Model 98:1-12. https:// doi.org/10.1016/S0304-3800(96)01932-1

Vauhkonen J, Berger A, Gschwantner T et al (2019) Harmonised projections of future forest resources in Europe. Ann For Sci 76:79. https://doi.org/10.1007/s13595-019-0863-6

Veblen TT, Hadley KS, Nel EM et al (1994) Disturbance regime and disturbance interactions in a Rocky Mountain Subalpine Forest. J Ecol 82:125-135. https://doi.org/10.2307/2261392

Verkerk PJ, Anttila P, Eggers J et al (2011) The realisable potential supply of woody biomass from forests in the European Union. For Ecol Manag 261:2007-2015. https://doi.org/10.1016/j. foreco.2011.02.027

Vidal C, Lanz A, Tomppo E et al (2008) Establishing forest inventory reference definitions for forest and growing stock: a study towards common reporting. Silva Fenn 42:247-266. https:// doi.org/10.14214/sf.255

Vidal C, Alberdi I, Hernández L, Redmond J (2016a) National Forest Inventories: assessment of wood availability and use, 1 st edn. Springer International Publishing, Cham

Vidal C, Alberdi I, Redmond J et al (2016b) The role of European National Forest Inventories for international forestry reporting. Ann For Sci. https://doi.org/10.1007/s13595-016-0545-6

Wang Y-P, Trudinger CM, Enting IG (2009) A review of applications of model-data fusion to studies of terrestrial carbon fluxes at different scales. Agric For Meteorol 149:1829-1842. https:// doi.org/10.1016/j.agrformet.2009.07.009

Wang T, O'Neill GA, Aitken SN (2010) Integrating environmental and genetic effects to predict responses of tree populations to climate. Ecol Appl 20:153-163. https://doi. org/10.1890/08-2257.1

Waring RH, Coops NC, Landsberg JJ (2010) Improving predictions of forest growth using the 3-PGS model with observations made by remote sensing. For Ecol Manag 259:1722-1729. https://doi.org/10.1016/j.foreco.2009.05.036

Weiskittel A, Hann D, Kershaw J, Vanclay J (2011) Forest growth and yield modeling

Wilson B, Howard R (1968) A computer model for cambial activity. For Sci 14:77-90

Yang Y, Anderson M, Gao F et al (2020) Investigating impacts of drought and disturbance on evapotranspiration over a forested landscape in North Carolina, USA using high spatiotemporal resolution remotely sensed data. Remote Sens Environ 238:111018. https://doi.org/10.1016/j. rse.2018.12.017

Youhua R, Li X, Sun R et al (2016) Spatial representativeness and uncertainty of eddy covariance carbon flux measurements for upscaling net ecosystem productivity to the grid scale. Agric For Meteorol 230-231:114-127

Yousefpour R, Temperli C, Jacobsen JB et al (2017) A framework for modeling adaptive forest management and decision making under climate change. Ecol Soc 22. https://doi.org/10.5751/ ES-09614-220440

Yousefpour R, Augustynczik ALD, Reyer CPO et al (2018) Realizing mitigation efficiency of European commercial forests by climate smart forestry. Sci Rep 8:1-11. https://doi. org/10.1038/s41598-017-18778-w

Yuan W, Liu S, Yu G et al (2010) Global estimates of evapotranspiration and gross primary production based on MODIS and global meteorology data. Remote Sens Environ 114:1416-1431. https://doi.org/10.1016/j.rse.2010.01.022

Zell J (2018) Climate sensitive tree growth functions and the role of transformations. Forest 9

Zell J, Rohner B, Thürig E, Stadelmann G (2019) Modeling ingrowth for empirical forest prediction systems. For Ecol Manag 433:771-779. https://doi.org/10.1016/j.foreco.2018.11.052

Zellweger F, De Frenne P, Lenoir J et al (2020) Forest microclimate dynamics drive plant responses to warming. Science (80-) 368:772-775. https://doi.org/10.1126/science.aba6880

Zhang K, Kimball JS, Running SW (2016) A review of remote sensing based actual evapotranspiration estimation. WIREs Water 3:834-853. https://doi.org/10.1002/wat2.1168 
Zurbriggen N, Nabel JEMS, Teich M et al (2014) Explicit avalanche-forest feedback simulations improve the performance of a coupled avalanche-forest model. Ecol Complex 17:56-66. https://doi.org/10.1016/j.ecocom.2013.09.002

Zweifel R, Eugster W, Etzold S et al (2010) Link between continuous stem radius changes and net ecosystem productivity of a subalpine Norway spruce forest in the Swiss Alps. New Phytol 187:819-830. https://doi.org/10.1111/j.1469-8137.2010.03301.x

Open Access This chapter is licensed under the terms of the Creative Commons Attribution 4.0 International License (http://creativecommons.org/licenses/by/4.0/), which permits use, sharing, adaptation, distribution and reproduction in any medium or format, as long as you give appropriate credit to the original author(s) and the source, provide a link to the Creative Commons license and indicate if changes were made.

The images or other third party material in this chapter are included in the chapter's Creative Commons license, unless indicated otherwise in a credit line to the material. If material is not included in the chapter's Creative Commons license and your intended use is not permitted by statutory regulation or exceeds the permitted use, you will need to obtain permission directly from the copyright holder.

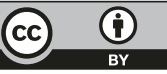

